\title{
Identity and distribution of southern African sciaenid fish species of the genus Umbrina
}

\section{K Hutchings \& MH Griffiths}

To cite this article: K Hutchings \& MH Griffiths (2005) Identity and distribution of southern African sciaenid fish species of the genus Umbrina , African Journal of Marine Science, 27:1, 1-21, DOI: 10.2989/18142320509504064

To link to this article: http://dx.doi.org/10.2989/18142320509504064

册 Published online: 08 Jan 2010.

Submit your article to this journal $₫$

Џll Article views: 36

Q View related articles $\asymp$

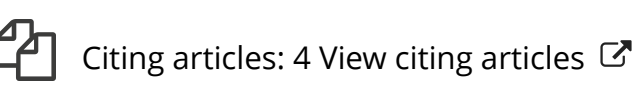




\title{
Identity and distribution of southern African sciaenid fish species of the genus Umbrina
}

\author{
K Hutchings ${ }^{1 *}$ and MH Griffiths ${ }^{2}$ \\ ${ }^{1}$ Department of Zoology and Marine Biology Research Institute, University of Cape Town, Rondebosch 7700, South Africa \\ ${ }^{2}$ Formerly Marine and Coastal Management, Department of Environmental Affairs and Tourism, Private Bag X2, Rogge Bay \\ 8012, South Africa; now Ministry of Fisheries, PO Box 1020, Wellington, New Zealand \\ *Corresponding author, e-mail: hutching@botzoo.uct.ac.za
}

Two Umbrina species, $U$. canariensis Valenciennes 1843 and $U$. robinsoni Gilchrist and Thompson 1908, are recognised from southern Africa. The latter species was hitherto believed to be a synonym of Umbrina ronchus Valenciennes 1843 (type locality Canary Islands). $U$. canariensis is distributed along the South Africa eastern seaboard from Cape Point to Sodwana Bay and $U$. robinsoni is known from False Bay to Madagascar and Oman. African Umbrina taxonomy has, however, been hindered by geographic samples that were either too few or consisted of specimens of disparate length; and as a result the identification and distribution of South African Umbrina species was confused. Morphological comparison of a large number of South African Umbrina with specimens from the type locality (Canary Islands) confirmed the identity of South African $U$. canariensis and allowed for an expanded description of the species. However, differences between specimens of $U$. ronchus and those of the second South African species $(n=251)$ led us to resurrect $U$. robinsoni (Gilchrist and Thompson 1908) as a valid name for this species. $U$. robinsoni differs from $U$. ronchus in having a smaller supraoccipital crest and thus a less steep pre-dorsal profile; a shallower preorbital bone (13-21\% head length [HL] vs $21 \% \mathrm{HL})$; and a shorter nostril-orbit distance $(2.4-6.9 \%$ HL vs $7.8-8.5 \%$ HL). Colour patterns also differ between the two species, with $U$. ronchus lacking the oblique, wavy, white stripes evident on the flanks of $U$. robinsoni. $U$. ronchus does not occur in South African waters, and is an eastern Atlantic species occurring from Gibraltar to Angola. Specimens from the east coast of Africa (Moçambique to Gulf of Oman) that were previously identified as $U$. ronchus are $U$. robinsoni.
Differences between $U$. robinsoni and $U$. canariensis include: a lower modal number of soft dorsal fin rays, (22-27 vs 24-30); less deep body depth, (26-36\% standard length [SL] vs 33-39\% SL); shorter pectoral fin length $(15-21 \%$ SL vs $20-25 \%$ SL); longer caudal peduncle length (26-34\% SL vs $21-28 \%$ SL) and snout length $(27-38 \%$ HL vs $23-32 \% \mathrm{HL})$; and smaller orbit diameter $(14-33 \% \mathrm{HL}$ vs $23-34 \% \mathrm{HL})$. Otoliths of $U$. robinsoni differ from those of $U$. canariensis in being smaller, less elongate, lacking a massive post-central umbo and having a post-dorsal spine remnant. The body colour and nature of the striping pattern on the flanks differs markedly between the species: in $U$. robinsoni the oblique stripes are thin, wavy, white lines; in $U$. canariensis the oblique stripes are thicker, nearly straight and brown; $U$. robinsoni also lacks the triangleshaped mark on the outer operculum and the dark pigmentation of the inner operculum that is found on $U$. canariensis. Spatial analysis of South African specimens collected with a variety of gear revealed $U$. robinsoni to be a shallow-water species found from the surf-zone to $40 \mathrm{~m}$, whereas $U$. canariensis occurs predominantly from 40 to $100 \mathrm{~m}$ depth. Although both species occur throughout the South African eastern seaboard, $U$. canariensis is most common west of the Kei River, where the shelf is wider. Examination of three specimens of $U$. steindachneri Cadenat 1950 confirmed the presence of a fourth sub-Saharan Umbrina species that is limited to tropical West African waters from Senegal to Angola. U. steindachneri differs from the other African Umbrina in having a high number of soft dorsal rays (28-29), a greater 3rd dorsal spine length $(25-27 \% \mathrm{SL})$ and a very pronounced and convoluted striping pattern on the flanks.

Keywords: distribution, habitat, morphometrics, taxonomy, Umbrina

Introduction

The genus Umbrina is unique among the Sciaenidae in having a worldwide distribution; occurring in tropical and temperate continental shelf and upper slope waters (Sasaki 1989, Walker and Radford 1992). It is distinguished from 
other genera in the family by the presence of a simple (without appendages), wholly abdominal swimbladder and a chin barbel with a median pore at its tip (Trewavas 1964, 1977, Chao 1986, Walker and Radford 1992).

The taxonomy of the New World Umbrina species has been well researched; Gilbert (1966) provided a review of the four species recorded in the western Atlantic and Walker and Radford (1992) reviewed the eight Pacific species. In the Old World, four species are described from the eastern Atlantic (Chao 1986, Chao and Trewavas 1990). Dardignac (1961) analysed distinguishing characteristics between $U$. cirrosa (Linnaeus 1758), $U$. canariensis Valenciennes 1843 and $U$. ronchus Valenciennes 1843 (using the synonym $U$. fusca) from specimens collected off the coast of Morocco. Two of these, $U$. canariensis and $U$. ronchus, appear to have particularly wide distributions. The former was thought to occur from the western Mediterranean and West African coast to Cape Point (South Africa) and into the western Indo-Pacific as far as Pakistan and the latter along the West African coast from Gibraltar to Angola, also in the western Indo-Pacific off the coasts of South Africa and Moçambique to Oman (Heemstra 1986, Randall 1995, Sasaki 1996).

The fourth African species, $U$. steindachneri (Cadenat 1951), was described from the coast of Senegal; the type is believed to be lost (Chao and Trewavas 1990) and no detailed description of this species morphometrics exists. Chao (1986) suspected that $U$. steindachneri might be synonymous with $U$. canariensis, but later Chao and Trewavas (1990) stated that the species was valid.

The holotype of $U$. ronchus was believed to be lost (Trewavas 1964) and Palmer (1966) described a neotype from one of two specimens collected from the type locality, the Canary Islands. The dry and dissected holotype was later found (Bauchot and Desoutter 1987), but owing to its means of preservation is of limited value for morphometric measurements. Palmer (1966) compared the Canary Islands specimens to a single, large $U$. capensis Pappe 1853 specimen from False Bay, South Africa, and suggested that the two species may be synonymous (Table 1).

In a review of the Indo-Pacific Sciaenidae, Trewavas (1977) examined 12 specimens of $U$. canariensis and $U$. sinuata (Day 1876), including seven South African specimens (Table 1), but did not compare these with specimens from the type locality (Canary Islands). Three specimens of $U$. ronchus were examined by Trewavas (1977), the neotype plus another specimen from the Canary Islands and one specimen from False Bay, South Africa (Table 1). The morphometrics of these three specimens were compared with those for $U$. robinsoni based on the original descriptions for $U$. robinsoni and $U$. angustilineata by Gilchrist and Thompson (1908, 1911). Trewavas (1977) highlighted the need for further taxonomic research on the South African Umbrina, specifically to investigate the possible synonymy of $U$. ronchus and $U$. robinsoni and also the possible presence of both $U$. canariensis and $U$. sinuata in the region.

Later authors accepted the synonymy of $U$. ronchus and $U$. robinsoni, as well as that of $U$. sinuata and $U$. canariensis (Heemstra 1986, Chao and Trewavas 1990), but no scientists had actually compared a large sample of South African specimens of a similar size range with the type specimens. In the most recent review of the Indian Ocean Sciaenidae, Sasaki (1996) did examine a reasonable sample of South African $U$. canariensis and compared these with specimens from other regions, including a similar size syntype of $U$. canariensis (Table 1 ). Sasaki (1996), however, examined only two small South African $U$. ronchus specimens and the much larger, dry holotype. In this review, Sasaki (1996) stressed that most of the diagnostic characters between $U$. ronchus and $U$. canariensis are either overlapping or involve allometric changes, making species separation difficult.

Along the eastern seaboard of South Africa, Umbrina species are an important component of recreational shoreangling and spearfishing catches (Bennett et al. 1994, Mann et al. 1997), as well as constituting an appreciable bycatch of beach-seines (Lamberth et al. 1994), inshore trawlers (Japp et al. 1994) and boat-based linefishers (Marine and Coastal Management, unpublished data). There has been some confusion about the identification and distribution of the species; $U$. ronchus was believed to be limited to KwaZulu-Natal waters, whereas $U$. canariensis was thought to be the species caught in the Eastern and South-Western Cape (Heemstra 1986). Fishers and researchers, however, maintained that there were at least two species in Cape waters. Many inshore South African fish species have been overexploited and there is an urgent need to develop species specific, scientifically-based management plans (Griffiths et al. 1999). If this is to be achieved for South African Umbrina species, clarity on the identification and distribution of stocks or species is urgently needed.

In this paper, we provide expanded descriptions of $U$. canariensis and $U$. robinsoni based on large samples $(n=$ 118 and 251 respectively) collected along the entire South African eastern seaboard (Cape Point to Moçambique border). These are statistically compared using 25 morphological measurements to each other and to specimens of $U$. ronchus, $U$. canariensis and $U$. steindachneri from the type localities (Canary Islands and Senegal). The distribution patterns of South African Umbrina are investigated by spatial analyses of specimens collected throughout the shelf region.

\section{Material and Methods}

A total of 322 South African specimens was collected and preserved by the authors. Catch methods included beachseining, trawling, spear- and linefishing. Gonads and otoliths were removed from specimens prior to preservation, but this was done in a manner to limit damage to the fish (the pectoral girdle was not cut and gills were not removed). Preservation involved injection with $40 \%$ formalin solution and immersion in a $10 \%$ formalin solution for 30 days; thereafter specimens were rinsed in freshwater for three days and stored in $70 \%$ isopropanol. Measurements were only taken after a minimum of 30 days in the isopropanol, i.e. once the preservation had stabilised. Museum specimens examined include an additional 38 South African 
Table 1: Old World Umbrina specimens examined by earlier researchers

\begin{tabular}{|c|c|c|c|c|}
\hline Source & Specimens examined $(\mathrm{n})$ & $\begin{array}{c}\text { Museum and registration } \\
\text { number }\end{array}$ & Locality & Size range (SL, mm) \\
\hline \multirow[t]{3}{*}{ Palmer (1966) } & U. ronchus (2) & $\begin{array}{l}\text { BMNH 1964.12.30. 1-2, } \\
\text { neotype + one other }\end{array}$ & $\begin{array}{l}\text { Canary Islands (Las } \\
\text { Palmas fish market) }\end{array}$ & 444,484 \\
\hline & $\begin{array}{l}U . \text { capensis }(1)= \\
U \text {. ronchus ? }\end{array}$ & $\mathrm{BMNH}$ - no number provided & South Africa, False Bay & $705 \mathrm{TL}$ \\
\hline & U. canariensis & $\mathrm{BMNH}-$ no number provided & & Canary Islands \\
\hline \multirow[t]{5}{*}{ Trewavas (1977) } & U. ronchus $(2)$ & BMNH 1964.12.30.1-2 & $\begin{array}{l}\text { Canary Islands (Las } \\
\text { Palmas fish market) }\end{array}$ & 444,484 \\
\hline & U. ronchus (1) & BMNH 1808.5.25.1 & South Africa, False Bay & $\begin{array}{l}595 \text { (same specimens as } \\
\text { Palmer 1966) }\end{array}$ \\
\hline & U. canariensis $(3)$ & BMNH 1935.5.11.121-123 & Angola & $229-290$ \\
\hline & U. canariensis $(7)$ & $\begin{array}{l}\text { BMNH 1935.5.2.171, } \\
\text { 1897.12.17.15, } \\
\text { 1891.10.21.5, 1905.6.8.31, } \\
\text { 1919.9.12.17-18, } \\
\text { 1903.12.31.1 }\end{array}$ & $\begin{array}{l}\text { South Africa, } \\
\text { Cape of Good Hope, } \\
\text { Mossel Bay, Algoa Bay, } \\
\text { Durban, Amatikula }\end{array}$ & $59.5-361$ \\
\hline & U. canariensis $(2)$ & $\begin{array}{l}\text { BMNH 1887.11.11.164, } \\
\text { (stuffed holotype of } U . \text { striata) } \\
\text { 1891.2.9.16 }\end{array}$ & India, Muscat & 334,258 \\
\hline \multirow[t]{10}{*}{ Sasaki (1996) } & U. ronchus (2) & $\begin{array}{l}\text { ANSP 55096, } \\
\text { BMNH 19.3.12.31 }\end{array}$ & $\begin{array}{l}\text { South Africa, Durban, } \\
\text { KwaZulu-Natal }\end{array}$ & $157.7,82.7$ \\
\hline & $U$. ronchus (1) & $\begin{array}{l}\text { MNHN } 5764 \text { (dry, dissected } \\
\text { holotype of } U \text {. ronchus) }\end{array}$ & Canary Islands & 434 \\
\hline & U. canariensis (13) & $\begin{array}{l}\text { ANSP } 63896, \text { BMNH } \\
\text { 1891.10.21.5, } \\
\text { 1919.2.12.17-18, USNM } \\
324683,(10)\end{array}$ & $\begin{array}{l}\text { South Africa, Durban, } \\
\text { Algoa Bay, KwaZulu-Natal } \\
(60-70 \mathrm{~m})\end{array}$ & $\begin{array}{l}56.9-188 \text { (three same } \\
\text { as Trewavas 1977) }\end{array}$ \\
\hline & U. canariensis $(4)$ & USNM 324682 & Pakistan (90-101m) & $194-280.5$ \\
\hline & U. canariensis $(2)$ & $\begin{array}{l}\text { BMNH 1887.11.11.164 } \\
\text { (holotype of } U . \text { striata), } \\
1891.2 .9 .16\end{array}$ & India, Muscat & $337,254.1$ \\
\hline & U. canariensis $(2)$ & BPBM 35903, 35940 & Southern Oman $(4-6 m)$ & $?, 124$ \\
\hline & U. canariensis $(2)$ & $\begin{array}{l}\text { CAS (SU) } 10584 \text { (holotype } \\
\text { of U. valida) MNHN A5669 } \\
\text { (syntype of U. canariensis) }\end{array}$ & Canary Islands & $299.4,299.5$ \\
\hline & U. canariensis (1) & BMNH 1985.7.9.247 & Beira, Moçambique & 159.4 \\
\hline & U. canariensis (1) & $\begin{array}{l}\text { MNHN } 7307 \text { (syntype of } \\
\text { U. lafonti) }\end{array}$ & Gulf of Gascony & 272.5 \\
\hline & U. canariensis (1) & USNM 306321 & Gulf of Aden (30-36m) & $558 ?$ \\
\hline
\end{tabular}

specimens, two $U$. ronchus from the Canary Islands (type locality), seven $U$. canariensis from the North-East Atlantic (Canary Islands, Morocco and France) and two $U$. canariensis from Angola. Institutional abbreviations follow Leviton et al. (1985). Material examined is listed after each description. The letters $\mathrm{F}$ (female), $\mathrm{M}$ (male) and $\mathrm{J}$ (juvenile - specimens too small to be sexed) are used to indicate sex. Standard length (SL) measured using a flat steel ruler to the nearest $\mathrm{mm}$ is used throughout, unless otherwise stated. Notes on the colour and pigmentation of species were made from fresh specimens unless indicated otherwise.

Counts and measurements generally followed the methods of Hubbs and Lagler (1964), with modifications listed below. Gill-rakers were counted on the first arch and do not include rudiments (structure wider than long). The raker at the epibranchial and ceratobranchial joint was included in the 'lower gill-raker' count. Counts of rostral pores included marginal pores that are typically lobed, whereas the mental pore count does not include the one at the tip of the barbel. Measurements were taken using precision calipers to the nearest $0.1 \mathrm{~mm}$. Body depth was measured between the origins of the dorsal and pelvic fins. The head length $(\mathrm{HL})$ measurement included the membranous, most posterior edge of the operculum. Nostril-orbit distance was measured from the posterior 'long nostril' to the anterior edge of the orbit. The least fleshy interorbital width was measured. The 'inter-round nostril' distance was measured between the anterior 'round nostrils'. The depth of the preorbital (lachrymal) bone was measured as the shortest distance between the margin of the orbit and the ventral margin of the bone close to the origin of the upper jaw. Dorsal caudal peduncle length was measured obliquely from the posterior end of the dorsal fin to the intersection of the lateral line and the caudal fin base. Ventral caudal peduncle length was measured in a similar 
fashion from the posterior end of the anal fin base. Pelvic and anal fin lengths were measured from the fin origin to the tip of the longest ray. Pectoral fin length was taken from the origin of the most dorsal ray to the tip of the longest ray; if pectoral fin lengths differed, the longest was used. Obviously broken fins or spines (present on many specimens that were obtained by trawling) were not measured. Anal spine width was measured at the base of the spine. Scale measurements were taken from a scale removed where the tip of the appressed pectoral fin touched the body.

Measurements were expressed as percentages of $\mathrm{HL}$ and/or SL. For the South African species, U. canariensis and $U$. robinsoni, morphometric ratios were arcsine transformed and compared using ANOVAs. Frequency distributions of meristic counts were compared using a Kolmogorov-Smirnov test. The sagittal otoliths of $30 \mathrm{U}$. canariensis and $30 \mathrm{U}$. robinsoni were examined and measurements of otolith length, height and post-dorsal edge to cauda distance were taken. These measurements were expressed as proportions; arcsine transformed and compared using t-tests. Linear regressions of fish total length vs otolith length and height were calculated and the slopes compared using t-tests (Zar 1996). Specimens of $U$. ronchus, $U$. canariensis and $U$. steindachneri from the type locality were compared to similar-sized South African specimens using multivariate methods. Differences in morphometric ratios were displayed in dendrograms and multi-dimensional scaling (MDS) plots based on normalised Euclidean distance using the PRIMER 5.2.2 software package (Plymouth Marine Laboratory, Plymouth, UK). Radiographs of the skulls of two $U$. ronchus from the type locality and $12 U$. robinsoni from South Africa were examined and the distance from the joint of the first vertebra to the most dorsal point of the supraoccipital crest was measured.

The distributions and habitats of $U$. canariensis and $U$. robinsoni in South African waters were determined by analysis of research and recreational catch data. During sampling it became apparent that in the Cape $U$. canariensis occurs farther offshore, in deeper water (40-150m depth) than U. robinsoni, which typically inhabits the surf-zone and shallow sub-tidal reefs (Table 2). Consequently, demersally trawled Umbrina from the Cape consist entirely of $U$. canariensis (a few are landed by linefishing boats operating in deep water), whereas rockand-surf anglers, spearfishers and beach-seine operations land $U$. robinsoni.

Marine and Coastal Management conducts annual demersal biomass surveys based on the swept-area method, which are used to provide biomass estimates for species exploited by the South African hake-directed trawl fishery. West Coast (Namibian border to Cape Agulhas) and South Coast (Cape Agulhas to Port Alfred) cruises are undertaken. On each cruise, stratified (by depth zone: 0-50m, 51-100m, 101-200m and 200-500m), semirandomly selected $5 \times 5$ nautical mile blocks were trawled (according to the ratio of blocks per stratum). Trawls were conducted over soft substratum using a 180-foot German trawl fitted with a 25-mm mesh liner. Trawl duration was limited to 30 minutes; results of shorter trawls have been standardised to that time. For a more complete description of DBS methods see Badenhorst and Smale (1991).

Catch per unit effort data for $U$. canariensis from demersal biomass surveys conducted during the period 1986-1999 were plotted graphically using SURFER 7 software (Golden Software, Golden, USA). Occurrences of U. robinsoni were determined from the records of shore-angling and spearfishing club competitions and research catches made by the authors over a two-year period (2001-2002).

\section{Systematic Account}

\section{Umbrina Cuvier}

Umbrina - Cuvier 1817: 297. Type species Sciaena cirrosa Linnaeus 1758 , by monotypy.

Attilus - Gistel 1848: 109. Type species Sciaena cirrosa Linnaeus 1758, by monotypy.

Asperina - Ostroumoff 1896: 30. Type species Asperina improviso (= U. cirrosa) Ostroumoff 1896, by monotypy.

\section{Description}

Genus description generally follows Trewavas (1977), Chao (1986) and Walker and Radford (1992). Moderately elongate, deep-bodied sciaenid fishes with an arched dorsal profile and relatively straight ventral margin. Wholly abdominal, carrot-shaped swimbladder without append-

Table 2: Distribution of $U$. canariensis $(U . c$.$) and U$. robinsoni $(U . r$.$) specimens showing percentage of total number sampled in different$ depth zones and regions during 2001 and 2002

\begin{tabular}{|c|c|c|c|c|c|c|c|c|}
\hline \multirow[b]{2}{*}{ Region } & \multicolumn{2}{|c|}{ Surf-zone } & \multicolumn{2}{|c|}{ Surf-zone-30m } & \multicolumn{2}{|c|}{$31-150 m$} & \multicolumn{2}{|c|}{ n (all depths) } \\
\hline & $\%$ U. $r$. & $\%$ U. C. & $\%$ U. $r$. & $\%$ U. c. & $\%$ U. $r$. & $\%$ U.c. & U. $r$. & U. c. \\
\hline SWC & 99.9 & 0.1 & * & - & - & - & 116 & 2 \\
\hline SC & 100 & - & * & - & - & 100 & 330 & 180 \\
\hline EC & 100 & - & 6 & 94 & - & 100 & 8 & 469 \\
\hline KZN & 100 & - & 100 & - & - & 100 & 365 & 2 \\
\hline n (all regions) & 454 & 1 & 365 & 31 & & 618 & 819 & 651 \\
\hline
\end{tabular}

SWC = False Bay-Cape Agulhas

$\mathrm{SC}=$ Cape Agulhas - Mossel Bay

$\mathrm{EC}=$ Mossel Bay-East London

$\mathrm{KZN}=$ East London-Moçambique border

* $U$. robinsoni is known to occur in this depth zone in the SWC and SC 
ages. Snout protuberant with 10 pores, mouth ventral with a single, pored barbel on chin flanked by two pairs of mental pores. Teeth small and villiform, outer row on upper jaw may be slightly enlarged. Margin of preopercle evenly and finely serrated, opercle ending in two small, flattened spines partly covered by skin. Sagittal otoliths thick, with suculus cauda sharply bent, not reaching ventral margin and ostium nearly reaching anterior edge of otolith. Scales ctenoid, lateral line scales extending to rear edge of caudal fin. Body colour ranges from silver-grey to yellow-brown and many species exhibit oblique stripes most prominent in the mid-dorsal area, usually absent or faint ventrally and on the head. Body colour darkens and stripes become obscure or absent in larger specimens of some species. Caudal fin S-shaped, pointed, truncate or slightly emarginated. Dorsal fin with $\mathrm{VIII}-\mathrm{XI}+\mathrm{I}$ spines (usually $\mathrm{X}$ $+I$ ) and 21-33 rays. Anal fin with II spines, the second usually long and robust and $5-10$ rays.

\section{Key to the sub-Saharan African species of Umbrina}

1a. Body depth $33-39 \%$ SL, orbit diameter $75-111 \%$ of snout length (for fish $>15 \mathrm{~cm}$ ), dorsal fin rays usually 27-29 (24-30). ...2

1b. Body depth $26-36 \%$ SL, orbit diameter $39-81 \%$ of snout length (for fish $>15 \mathrm{~cm}$ ), dorsal fin rays usually 25 (22-27). ..3

2a. Pectoral fin length $78-109 \%$ of ventral caudal peduncle length, 3rd dorsal spine length 14-22\% SL, preorbital bone depth $13-17 \% \mathrm{HL}$, inside gill cover darkly pigmented.......................................... canariensis

2b. Pectoral fin length $69-79 \%$ of ventral caudal peduncle length, 3rd dorsal spine length $25-27 \%$ SL, preorbital bone depth $17-18 \% \mathrm{HL}$, inside gill cover white or very lightly pigmented.................................. steindachneri

3a. Nostril-orbit distance 7.8-8.5\% HL, preorbital bone depth $18-24 \% \mathrm{HL}$, scale length $2.3-2.4 \% \mathrm{SL}$, dorsal head profile (between snout and first dorsal fin) steeply curved with clear inflection point above preopercle................................................. ronchus

3b. Nostril-orbit distance 2.4-6.9\% HL, preorbital bone depth $13-21 \% \mathrm{HL}$, scale length $2.4-3.8 \% \mathrm{SL}$, dorsal head profile smoothly convex with no clear inflection point above preopercle. U. robinsoni

\section{Umbrina canariensis Valenciennes 1843} (Figure 1)

Umbrina canariensis - Valenciennes 1843: 24 (Canary Islands). For details of synonymy see Chao and Trewavas (1990).

\section{Syntypes}

MNHN numbers 7608 and A 5669 (335mm and 300mm SL respectively from Canary Islands)
Material examined

Canary Islands: MNHN 2983 (176mm). France (Gulf of Gascony): MNHN 1898-0568 (163mm, Syntype of U. lafonti Moreau 1874). Morocco: MNHN 1912-208 (73mm); MNHN 1912-209 (74.3mm); MNHN 1912-210 (76.8mm); MNHN 1912-211 (66mm); MNHN 1912-212 (59.6mm). Angola: RUSI 69876 (F 276mm); RUSI 69875 (M 298mm). South Africa: Western Cape: RUSI 67515 (J 157mm). Southern Cape: RUSI 41988 (M 234mm); RUSI 35546 (M 286mm); RUSI 35545 (M 281mm); RUSI 67499 (F 210mm); RUSI 67500 (F 214mm); RUSI 67501 (F 228mm); RUSI 67502 (F 230mm); RUSI 67504 (F 240mm); RUSI 67506 (F 251mm); RUSI 67508 (F 261m); RUSI 67509 (F 265mm); RUSI 67512 (F 292mm); RUSI 67517 (M 216mm); RUSI 67518 (M 226mm); RUSI 67519 (M 229mm); RUSI 67520 (M 236mm); RUSI 67521 (M 240mm); RUSI 67522 (M 246mm); RUSI 67627 (M 267mm); RUSI 67630 (M 298mm); RUSI 67631 (M 313mm); SAM 36068 (7 M 206mm, $232 \mathrm{~mm}, 240 \mathrm{~mm}, 244 \mathrm{~mm}, 262 \mathrm{~mm}, 268 \mathrm{~mm}, 284 \mathrm{~mm} ; 4 \mathrm{~F} 211 \mathrm{~mm}$, $225 \mathrm{~mm}, 232 \mathrm{~mm}, 251 \mathrm{~mm}$ ). Eastern Cape: RUSI 12333c (M 254mm); RUSI 12333a (M 228mm); RUSI 12333b (F 246mm); RUSI (J 198mm); RUSI 12767a (F 219mm); RUSI 12767b (M 221mm); RUSI 12767c (M 196mm); RUSI 4918 (F 202mm); RUSI 41989 (M 218mm, M 221mm); RUSI 49104 (F 273mm); RUSI 12788 (F 159mm); RUSI 12768 (M 207mm); RUSI 14918 (F $171 \mathrm{~mm}$ ); RUSI 13324 (M 198mm); RUSI 5760 (F 311mm); RUSI 67503 (F 235mm); RUSI 67505 (F 247mm); RUSI 67507 (M 318mm); RUSI 67510 (F 277mm); RUSI 67511 (F 282mm); RUSI 67513 (F 310mm); RUSI 67514 (F 345mm); RUSI 67516 (M 198mm); RUSI 67523 (M 250mm); RUSI 67626 (M 260mm); RUSI 67628 (M 274mm); RUSI 67629 (M 283mm); SAM 36069 (3 M $226 \mathrm{~mm}, 255 \mathrm{~mm}, 299 \mathrm{~mm}$; 6 F $244 \mathrm{~mm}, 262 \mathrm{~mm}, 276 \mathrm{~mm}, 281 \mathrm{~mm}$, 299mm, 311mm). KwaZulu-Natal: RUSI 5607a (206mm); RUSI 5607b (169mm); RUSI 5607c (F 206mm); RUSI 10697 (259mm); RUSI 26206 (F 197mm).

Additional material examined - South Africa: Southern Cape: 2001.8.1 (F 244mm); 2001.8.6 (F 285mm); 2001.8.10 (M 214mm); 2001.8.15 (F 218mm); 2001.8.19 (F 229mm); 2001.8.22 (M 217mm); 2001.8.23 (F 264mm); 2001.8.24 (F 235mm); 2001.8.28 (F 239mm); 2001.8.32 (F 228mm); 2001.8.39 (M 263mm). Eastern Cape: 2001.16.1 (F 219mm); 2001.16.4 (F 236mm); 2001.16.7 (F 265mm); 2001.16.9 (M 284mm); 2001.16.10 (F 247mm); 2001.16.12 (M 212mm); 2001.16.13 (M 263mm); 2001.16.15 (M 226mm); 2001.16.16 (F 257mm); 2001.16.17 (F 266mm); 2001.16.19 (F 267mm); 2001.16.21 (F 255mm); 2001.16.23 (F $212 \mathrm{~mm}$ ); 2001.16.24 (F 285mm); 2001.16.25 (M 255mm); 2001.16.26 (M 246mm); 2001.16.29 (F 235mm); 2001.16.33 (M $236 \mathrm{~mm}) ; 2001.16 .36$ (F 235mm); 2001.16.38 (F 222mm); 2001.16.39 (F 227mm); 2001.16.40 (M 255mm); 2001.16.42 (M $296 \mathrm{~mm})$.

\section{Diagnosis}

Values for the specimens examined are range and (mode) for meristic counts or mean (in parenthesis) for measurements. In order to distinguish components of the expanded description, counts and measurements by Trewavas (1977) are given in square brackets.

A medium-size Umbrina species (max. 42cm TL for 3893 South African fish measured) with the following combination of characters: dorsal fin rays 24-30 (27) [26-29]; ${ }^{1}$ gillrakers 4-7 (6) + 8-11 (9); body depth 33-39 (36) [35-42]\% SL; pre-dorsal length 35-41 (38)\% SL; pectoral fin length 20-25 (23) [19-24]\% SL; ventral caudal peduncle length 21-28 (24)\% SL; 3rd dorsal spine length 14-22 (16)\% SL; anal fin length 16-27 (19) [13-21]\% SL; scale length

\footnotetext{
1 Dardignac (1961) reported a range of 26-31 for specimens from Morocco
} 


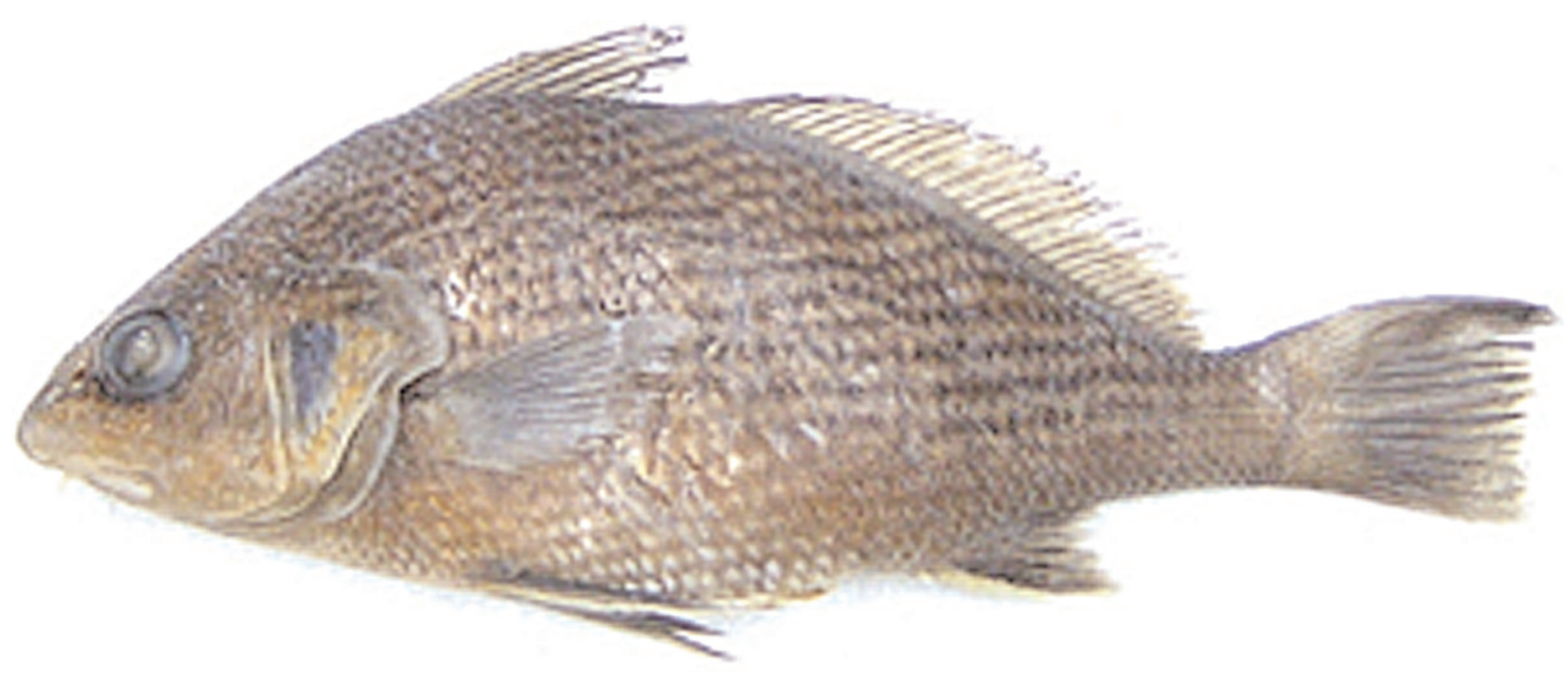

Figure 1: Female Umbrina canariensis, F 276mm SL, RUSI 69876, Angola

3.4-4.7 (4)\% SL; upper jaw length 10-13 (11)\% SL; head length 29-35 (32) [32-34]\% SL; snout length 23-32 (29) [27-31]\% HL; horizontal orbit diameter 23-34 (26) [23-33]\% HL; nostril-orbit distance 2-5.4 (4)\% HL; preorbital bone depth 13-17 (15.5) [15-19]\% HL.

\section{Description}

Counts and measurements are presented in Table 3. A compressed, deep-bodied Umbrina species with a relatively large head, orbit and upper jaw and short pointed snout (orbit diameter subequal to snout length). The orbit diameter measurement typically exhibits negative allometry with increasing size, whereas snout length is nearly isometric. The pectoral fin is long, usually the same length or longer than the pelvic fin; caudal fin truncate and body scales large. Drumming muscles are well developed in males, loosely attached to the ribs but firmly joined to the dorsal surface of the swimbladder; absent in females.

Body colour silver-grey, dark dorsally and lighter ventrally; fins generally light brown near bases, becoming dark to black near tips (Figure 1). Dark grey-black, broad stripes run obliquely on the flanks and may extend onto the dorsal part of head; stripes are most prominent dorsally and faint or absent below the level of the pectoral fin. Dark stripes were present on all South African and the two Angolan specimens examined (157-345mm SL), but are faint if the scales have been lost. On the seven MNHN specimens from the North-East Atlantic and Mediterranean examined, no stripes were visible, probably a result of the bleaching effect of long storage in alcohol (specimens were yellow or silver in colour). Inner side of operculum dark to black; a clear triangular-shaped mark, which is blue in fresh specimens and becomes dark or clear in preserved specimens, is present on the outer surface of the operculum level with the lower flattened spine.

Saggital otoliths rectangular, tapering to a blunt point anteriorly, broader and rounded posteriorly, moderately elongate, and becoming very thick with growth (Figure 2). A large, usually smooth and pointed post-central umbo is present on the lateral face, although this may be obscured by extensive ornamentation in some individuals. The dorsal margin is slightly convex with a high-point above the ostium-cauda join; the ventral edge is rounded, tapering upwards anteriorly. The most posterior point of the otolith is near the mid-point of the descending curve of the cauda, i.e. there is no evidence of a post-dorsal spine remnant. Otolith measurements are presented in Table 4 and otolith length and height to fish length relationships are shown in Figure 3.

\section{Remarks}

In their studies of old world Umbrina, Trewavas (1964), Palmer (1966) and Trewavas (1977) discuss the synonymy of $U$. canariensis with $U$. sinuata Day, 1876 and $U$. striata Boulenger, 1888. The latter two species names were ascribed to deep-bodied South African specimens with a large orbit and high dorsal ray count by Gilchrist and Thompson (1908, 1911, 1917), Barnard (1927) and Smith (1949, as Sciaena sinuata). Later authors described specimens from South Africa as $U$. canariensis (inter alia Heemstra 1986 and Chao and Trewavas 1990, based on Trewavas (1977) description of specimens from the region) and Sasaki (1996) who examined 26 specimens, 13 of which came from South Africa (Table 1).

In this study, further confirmation is provided of the presence of $U$. canariensis off the coast of southern Africa by comparison of 109 South African and two Angolan specimens with seven specimens from the North-East Atlantic. Five specimens from the coast of Morocco were much smaller (MNHN 1912-208-212, 60-77mm SL) than the South African specimens (157-345mm SL), but two (MNHN 2983, 176mm SL, Canary Islands - type locality and MNHN 1898-0568, 163mm SL, Gulf of Gascony, syntype of $U$. lafonti Moreau 1874) were near the lower 
Table 3: Morphological measurements and meristic data of Umbrina species examined. The symbols in column 'p' indicate a significant difference (ANOVA) between arcsine-transformed ratios of similar-sized $(157-350 \mathrm{~mm})$ South African U. canariensis and U. robinsoni for morphometric measurements $(\mathrm{df}=127-194)$ and Kolmogorov-Smirnov test for meristic counts

\begin{tabular}{|c|c|c|c|c|c|c|c|c|c|c|c|c|c|c|c|c|}
\hline \multirow[b]{3}{*}{ Parameters } & \multirow[b]{3}{*}{$p$} & \multirow[b]{3}{*}{$\mathrm{n}$} & \multicolumn{4}{|c|}{ Umbrina canariensis } & \multicolumn{5}{|c|}{ Umbrina robinsoni } & \multirow{2}{*}{\multicolumn{2}{|c|}{$\begin{array}{c}\text { Umbrina } \\
\text { ronchus }\end{array}$}} & \multirow{2}{*}{\multicolumn{3}{|c|}{$\begin{array}{c}\text { Umbrina } \\
\text { steindachneri } \\
\text { MNHN 1913, } \\
1982\end{array}$}} \\
\hline & & & \multirow[b]{2}{*}{ Mean } & \multirow[b]{2}{*}{ SD } & \multirow[b]{2}{*}{ Min. } & \multirow[b]{2}{*}{ Max. } & \multirow[b]{2}{*}{$\mathrm{n}$} & \multirow[b]{2}{*}{ Mean } & \multirow[b]{2}{*}{ SD } & \multirow[b]{2}{*}{ Min. } & \multirow[b]{2}{*}{ Max. } & & & & & \\
\hline & & & & & & & & & & & & 30.1 & 30.2 & 093 & 1298 & 1299 \\
\hline Standard Length (mm) & & 118 & & & 60 & 345 & 251 & & & 78 & 654 & 436 & 465 & 177 & 108 & 116 \\
\hline \multicolumn{17}{|l|}{ Measurements \% SL } \\
\hline Head length & $* *$ & 118 & 32 & 1.1 & 29 & 35 & 251 & 29 & 1.3 & 26 & 32 & 31 & 31 & 31 & 32 & 32 \\
\hline Body depth & $* *$ & 118 & 36 & 1.4 & 33 & 39 & 251 & 31 & 1.7 & 26 & 36 & 31 & 31 & 36 & 36 & 36 \\
\hline Pre-dorsal length & ** & 118 & 38 & 1.2 & 35 & 41 & 251 & 35 & 1.7 & 31 & 40 & 38 & 39 & 37 & 38 & 37 \\
\hline Snout-pelvic length & ** & 118 & 36 & 1.1 & 34 & 39 & 251 & 33 & 1.4 & 30 & 37 & 32 & 33 & 32 & 34 & 32 \\
\hline 3rd dorsal spine length & ** & 51 & 16 & 1.6 & 14 & 22 & 234 & 18 & 2.0 & 12 & 22 & 19 & & 27 & 25 & 25 \\
\hline Pectoral fin length & $* *$ & 113 & 23 & 1.0 & 20 & 25 & 250 & 18 & 1.0 & 15 & 21 & 18 & 18 & 19 & 21 & 22 \\
\hline Pelvic fin length & * & 118 & 22 & 1.4 & 19 & 26 & 251 & 20 & 1.5 & 17 & 25 & 20 & 19 & 23 & 24 & 26 \\
\hline Anal fin length & ** & 118 & 19 & 1.8 & 16 & 27 & 250 & 20 & 1.5 & 16 & 24 & 19 & 19 & 23 & 29 & 27 \\
\hline Dorsal CPD length & ** & 118 & 12 & 0.7 & 10 & 14 & 251 & 13 & 0.7 & 11 & 14 & 12 & 11 & 12 & 12 & 12 \\
\hline Ventral CPD length & $* *$ & 94 & 24 & 1.1 & 21 & 28 & 239 & 29 & 1.6 & 26 & 34 & 28 & 27 & 28 & 28 & 28 \\
\hline CPD depth & $* *$ & 118 & 10 & 0.4 & 9.0 & 12 & 251 & 10 & 0.7 & 8.6 & 12 & 8.7 & 9.5 & 10 & 12 & 10 \\
\hline Scale height & ** & 75 & 4.8 & 0.3 & 4.1 & 5.4 & 244 & 3.7 & 0.3 & 2.9 & 5.6 & 3.4 & 3.7 & 4 & 4 & 4 \\
\hline Scale length & $* *$ & 75 & 4.0 & 0.3 & 3.4 & 4.7 & 244 & 3.1 & 0.2 & 2.4 & 3.8 & 2.4 & 2.3 & 4 & 3 & 3 \\
\hline 2nd anal spine length & ns & 116 & 12 & 1.3 & 9.6 & 18 & 246 & 10 & 1.5 & 6.3 & 15 & 8.9 & & 14 & 17 & 14 \\
\hline 2nd anal spine width & * & 116 & 1.3 & 0.2 & 0.2 & 2.1 & 249 & 1.1 & 0.1 & 0.5 & 1.5 & 0.8 & 0.7 & 1 & 2 & 1 \\
\hline \multicolumn{17}{|l|}{ Measurements \% HL } \\
\hline Snout length & $* *$ & 118 & 29 & 1.5 & 23 & 33 & 251 & 34 & 1.5 & 27 & 38 & 35 & 38 & 30 & 30 & 30 \\
\hline Horizontal orbit & $* *$ & 118 & 26 & 2.2 & 23 & 34 & 251 & 19 & 2.9 & 14 & 33 & 16 & 16 & 27 & 28 & 28 \\
\hline Vertical orbit & $* *$ & 118 & 24 & 1.9 & 20 & 31 & 251 & 18 & 2.6 & 13 & 30 & 15 & 15 & 23 & 24 & 26 \\
\hline Inter-orbital width & $* *$ & 118 & 24 & 1.3 & 21 & 28 & 251 & 27 & 1.6 & 23 & 31 & 29 & 29 & 26 & 25 & 25 \\
\hline Nostril-orbit distance & ns & 118 & 4.0 & 0.7 & 2.0 & 5.4 & 251 & 4.6 & 0.9 & 2.4 & 6.9 & 7.8 & 8.5 & 4 & 4 & 5 \\
\hline Long nostril & $* *$ & 114 & 6.3 & 0.6 & 4.1 & 8.2 & 247 & 7.1 & 0.5 & 5.8 & 8.8 & 7.9 & 6.4 & 6 & 8 & 5 \\
\hline Inter-round nostril & ns & 116 & 20 & 0.8 & 18 & 23 & 251 & 20 & 0.8 & 18 & 22 & 21 & 21 & 22 & 20 & 19 \\
\hline Barbel length & $* *$ & 116 & 6.2 & 0.9 & 4.4 & 8.6 & 250 & 5.3 & 0.6 & 3.6 & 8.1 & 5.7 & 4.8 & 6 & 6 & 6 \\
\hline Preorbital depth & $* *$ & 94 & 16 & 0.9 & 13 & 17 & 237 & 18 & 1.0 & 13 & 21 & 21 & 21 & 18 & 16 & 18 \\
\hline Upper jaw length & ** & 118 & 34 & 1.4 & 31 & 40 & 251 & 32 & 1.0 & 29 & 37 & 32 & 32 & 34 & 33 & 31 \\
\hline Useful ratios & & & & & & & & & & & & & & & & \\
\hline † Orbit \% Snout length & ** & 111 & 88 & 7.5 & 75 & 111 & 246 & 57 & 8.4 & 39 & 81 & 46 & 41 & 89 & 91 & 92 \\
\hline Pec. fin \% Ventral CPD & $* *$ & 92 & 93 & 5.0 & 78 & 109 & 239 & 61 & 5.4 & 49 & 73 & 65 & 66 & 68 & 75 & 79 \\
\hline Meristic data & & & & & & & & & & & & & & & & \\
\hline 1st dorsal fin spines & ns & 118 & $10^{1}$ & & 9 & 11 & 249 & $10^{1}$ & & 8 & 10 & 10 & 10 & 10 & 10 & 10 \\
\hline 2nd dorsal fin spines & - & 118 & $1^{1}$ & & 1 & 1 & 249 & 11 & & 1 & 1 & 1 & 1 & 1 & 1 & 1 \\
\hline 2 nd dorsal fin rays & $* *$ & 117 & $27^{1}$ & & 24 & 30 & 249 & $25^{1}$ & & 22 & 27 & 25 & 25 & 28 & 29 & 29 \\
\hline Pectoral fin rays & ns & 117 & $17^{1}$ & & 15 & 17 & 246 & $17^{1}$ & & 15 & 18 & 16 & 16 & 16 & 16 & 16 \\
\hline Anal fin spines & - & 118 & $2^{1}$ & & 2 & 2 & 248 & $2^{1}$ & & 2 & 2 & 2 & 2 & 2 & 2 & 2 \\
\hline Anal fin rays & - & 118 & $7^{1}$ & & 7 & 7 & 247 & $7^{1}$ & & 7 & 7 & 7 & 7 & 7 & 7 & 7 \\
\hline Upper gill-rakers & $* *$ & 113 & $6^{1}$ & & 4 & 7 & 246 & $5^{1}$ & & 4 & 6 & 3 & 3 & 4 & 4 & 5 \\
\hline Lower gill-rakers & $*$ & 116 & $9^{1}$ & & 8 & 11 & 248 & $9^{1}$ & & 6 & 10 & 8 & 9 & 9 & 9 & 9 \\
\hline Lateral line scales & $* *$ & 88 & $49^{1}$ & & 47 & 52 & 229 & $50^{1}$ & & 48 & 54 & 51 & 50 & 49 & & \\
\hline Rostral pores & - & 118 & $10^{1}$ & & 10 & 10 & 248 & $10^{1}$ & & 10 & 10 & 10 & 10 & 10 & 10 & 10 \\
\hline Mental pores & - & 118 & $4^{1}$ & & 4 & 4 & 248 & $4^{1}$ & & 4 & 4 & 4 & 4 & 4 & 4 & 4 \\
\hline
\end{tabular}

ns $=p>0.05,{ }^{*}=p<0.05,{ }^{* *}=p<0.01$

$\dagger=$ the ratio does not include fish $<157 \mathrm{~mm} \mathrm{SL}$

$\mathrm{CPD}=$ caudal peduncle

$1=$ mode (not mean)

end of the range. Meristic data and measurements for these nine specimens fall within the range for the South African specimens or extend the range as expected for features that show allometric growth (Figures 4-6). The two larger fish were compared to 61 South African specimens (157-250mm SL) using multivariate methods. The dendrogram and MDS ordination plots show these two specimens grouping together with the South African fish, although slightly separated as would be expected by the smaller size of the specimens (Figure 7). 
U. robinsoni
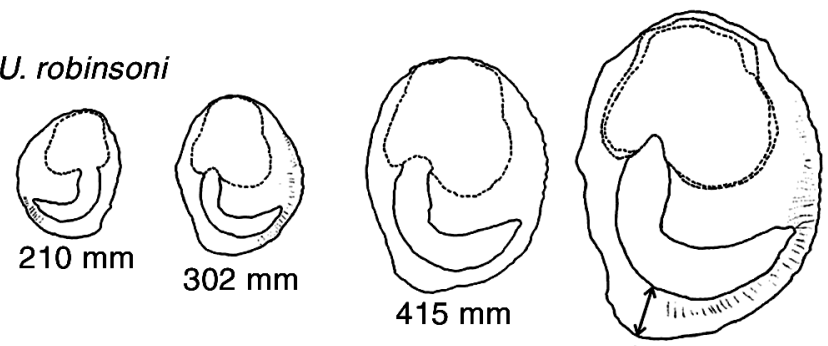

$U$. canariensis

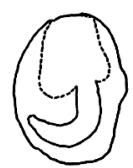

$218 \mathrm{~mm}$
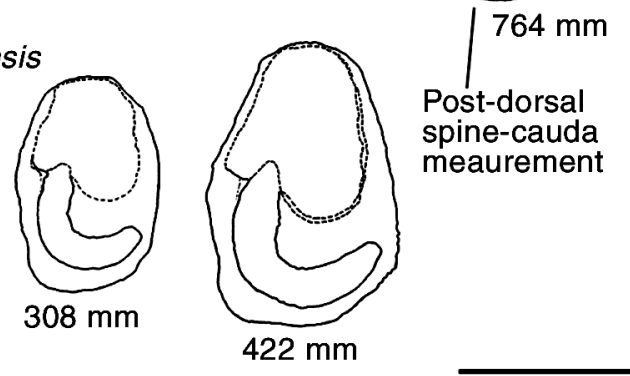

U. robinsoni
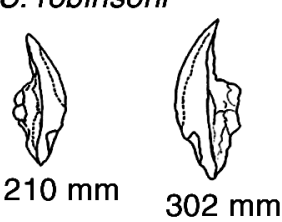

$210 \mathrm{~mm}$

$302 \mathrm{~mm}$
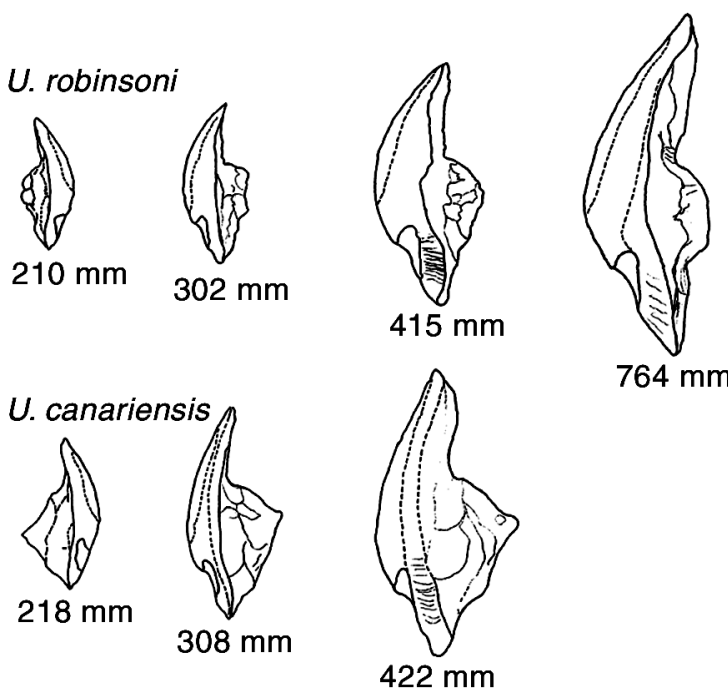

Figure 2: Medial and lateral views of $U$. canariensis and $U$. robinsoni otoliths showing inter-specific differences. Scale bar $=$ $10 \mathrm{~mm}$. Fish lengths (TL) are given

\section{Distribution and habitat}

Eastern Atlantic Ocean and western Mediterranean from the Bay of Biscay to southern Angola (Chao and Trewavas 1990) and possibly off the central-northern Namibian coast (one specimen from Swakopmund, JH Holtzhausen, Ministry of Fisheries and Marine Resources, Namibia, pers. comm.). U. canariensis appears to be absent from southern Namibia and the South African west coast; possibly due to environmental barriers (e.g. low dissolved oxygen and cool water temperatures) created by the Benguela upwelling system. Also known from the western Indian Ocean, from South Africa to Pakistan (Heemstra 1986, Sasaki 1996).

Off the South African coast, $U$. canariensis is most common along the South and East coasts between Cape Agulhas and East London, with centres of abundance on the eastern Agulhas Bank and Algoa Bay (Figures 8, 9).

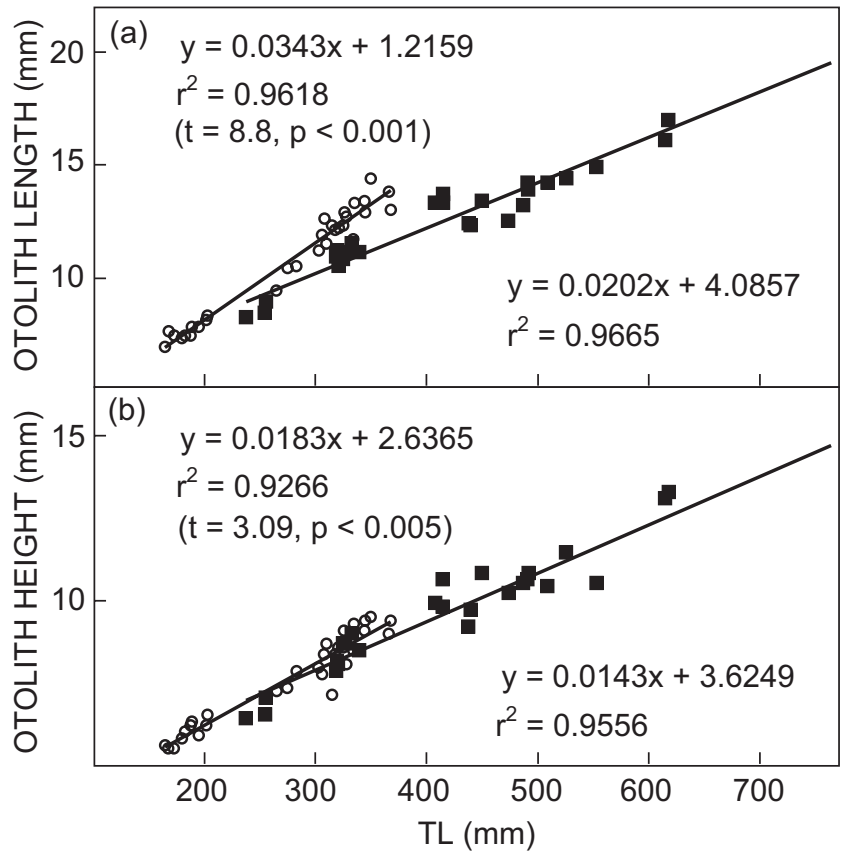

Figure 3: Relationship between (a) otolith length and TL and (b) otolith height and TL for South African U. canariensis (circles) and $U$. robinsoni (squares). Slopes of regression lines are significantly different

Table 4: Measurements of $U$. canariensis and $U$. robinsoni otolith morphology (t-test was conducted on arcsine-transformed ratios)

\begin{tabular}{|c|c|c|c|c|}
\hline Parameters & $\mathrm{OH}: \mathrm{OL}$ & OT:OH & OT:OL & PD-C:OL \\
\hline \multicolumn{5}{|c|}{ U. canariensis } \\
\hline Mean & 0.73 & 0.65 & 0.47 & 0.16 \\
\hline Min. & 0.59 & 0.48 & 0.37 & 0.13 \\
\hline Max. & 0.85 & 0.86 & 0.57 & 0.19 \\
\hline \multicolumn{5}{|c|}{ U. robinsoni } \\
\hline Mean & 0.77 & 0.52 & 0.39 & 0.22 \\
\hline Min. & 0.70 & 0.44 & 0.32 & 0.18 \\
\hline Max. & 0.82 & 0.62 & 0.47 & 0.25 \\
\hline $\mathrm{n}$ & 30 & 30 & 30 & 30 \\
\hline t-value & 2.63380 & -6.68647 & -7.28894 & 14.24155 \\
\hline $\mathrm{p}$ & $<0.05$ & $<0.001$ & $<0.001$ & $<0.001$ \\
\hline $\begin{array}{l}\mathrm{OH}=\text { Otolith } \\
\mathrm{OL}=\text { Otolith } \\
\mathrm{OT}=\text { Otolith } \\
\mathrm{PD}-\mathrm{C}=\text { Pos }\end{array}$ & $\begin{array}{l}\text { eight } \\
\text { ength } \\
\text { hickness } \\
\text { dorsal spin }\end{array}$ & auda dist & & \\
\hline
\end{tabular}

Preferred depth range is between 26-75m (Figure 10), with smaller size-classes more abundant in the shallower depth strata (Figure 11). During this study, two small $U$. canariensis $(157 \mathrm{~mm}$ and $172 \mathrm{~mm} \mathrm{SL})$ were collected from shallow water $(5 \mathrm{~m})$ in a False Bay beach-seine $\left(34^{\circ} 5^{\prime} \mathrm{S}, 18^{\circ} 35^{\prime} \mathrm{E}\right)$; these specimens probably represent the western extreme of the species range in South African waters. Another two specimens (227mm and $158 \mathrm{~mm} \mathrm{SL}$ ) were collected in deep water (approximately $80 \mathrm{~m}$ and $414 \mathrm{~m}$ ) off the central KwaZulu-Natal coast (by linefishing and crustacean trawl respectively). There are five specimens (169-259mm SL) in the RUSI collection from 


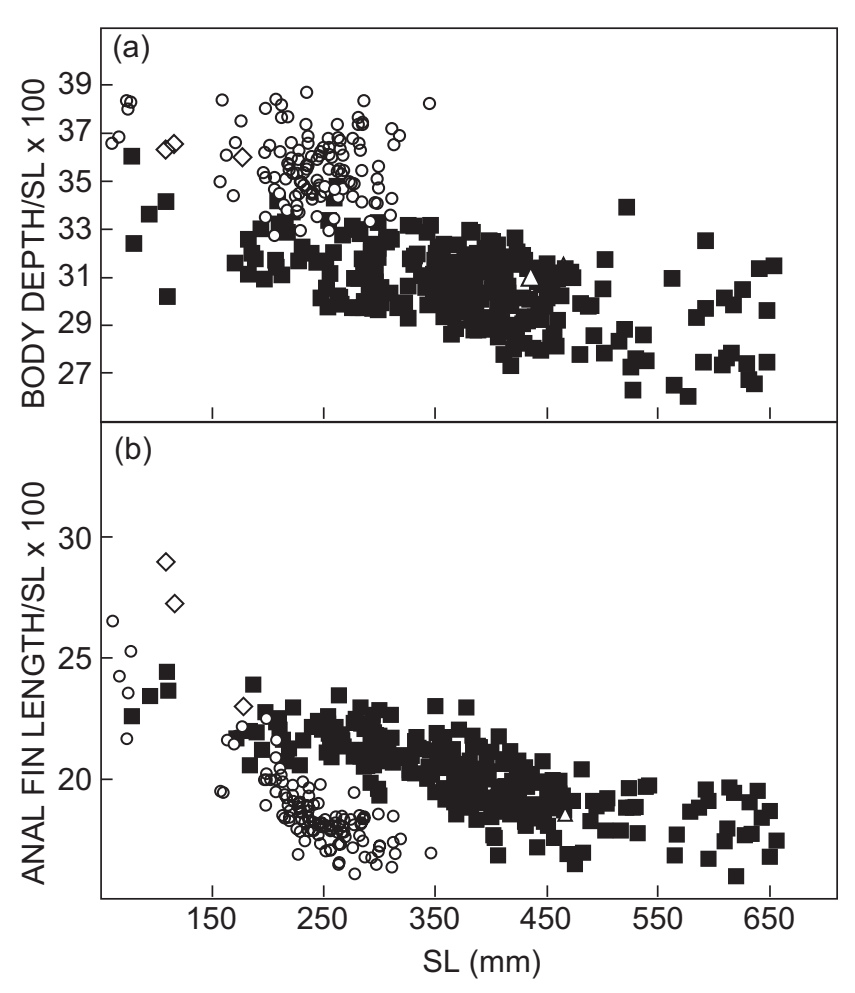

Figure 4: Relationship between (a) body depth and (b) anal fin length as \% SL and $\mathrm{SL}$ for $U$. canariensis (circles), $U$. robinsoni anal (squares), $U$. steindachneri (diamonds) and $U$. ronchus (triangles)

KwaZulu-Natal waters ('deep water off Pondoland' and 'Durban area', $\left.29^{\circ} 51^{\prime} S, 31^{\circ} 00^{\prime} E\right)$. Video footage taken in deep water $(130 \mathrm{~m})$ off Sodwano Bay in northern KwaZuluNatal $\left(32^{\circ} 41^{\prime} \mathrm{S}, 27^{\circ} 32^{\prime} \mathrm{E}\right)$ during coelacanth surveys confirms the presence of $U$. canariensis in that region. Demersal biomass surveys by the FRS Africana are not routinely conducted east of Port Alfred (Figure 8), but commercial prawn trawlers do operate off northern KwaZulu-Natal within the depth range $20-450 \mathrm{~m}$ and only one $U$. canariensis has been recorded as a bycatch in these fisheries (Fennessy 1994, ST Fennessy pers. comm.) suggesting that this species is scarce north of Durban.

\section{Umbrina steindachneri Cadenat 1951}

(Figure 12)

Umbrina steindachneri - Cadenat 1951, Poissons mer Sénégal: 221, Fig. 156 (Senegal).

Umbrina cirrhosa var. canariensis - Steindachner 1882:

7, PI. 2 (Fig. 1, Gorée).

Sciaena steindachneri - Collignon 1959: 9; Blache 1962: 59.

Umbrina steindachneri - Dardignac 1961: 274; Trewavas 1964: 113, 115; Sanches 1966: 109, Fig.; Williams 1968 — distribution; Blache et al. 1970: 300, Fig. 790; Chao and Trewavas 1981 (FAO sheets); Seret and Opic 1981: 256, 257, Fig.; Chao and Trewavas 1990: 826.

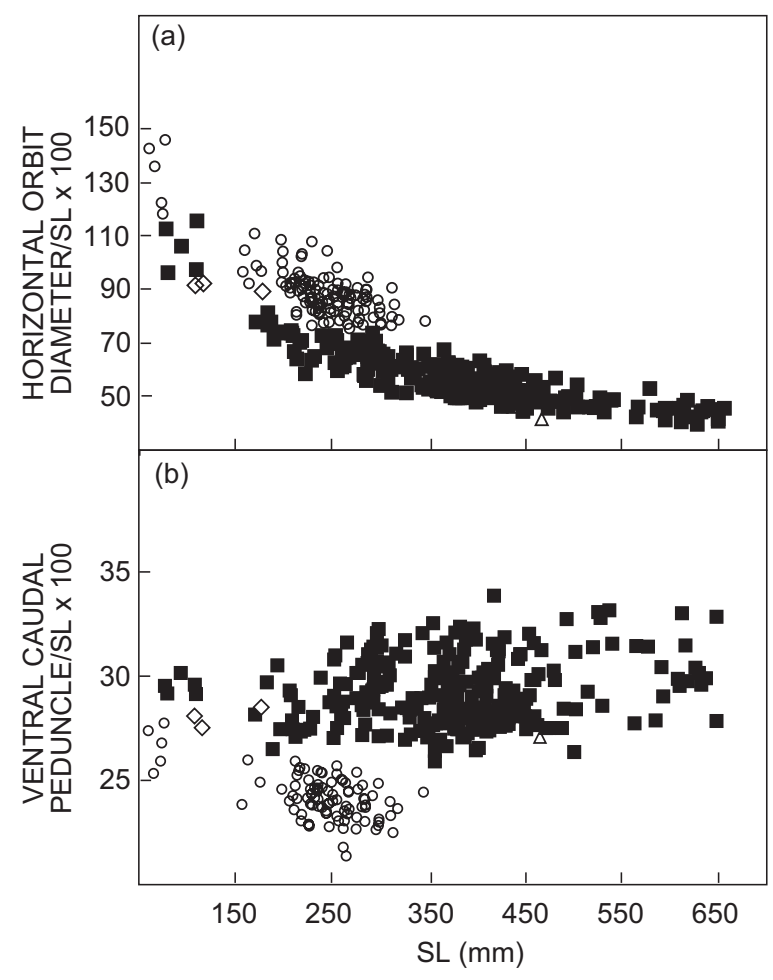

Figure 5: Relationship between (a) orbit diameter and (b) ventral caudal peduncle length as $\% \mathrm{SL}$ and $\mathrm{SL}$ for $U$. canariensis (circles), U. robinsoni (squares), U. steindachneri (diamonds) and $U$. ronchus (triangles)

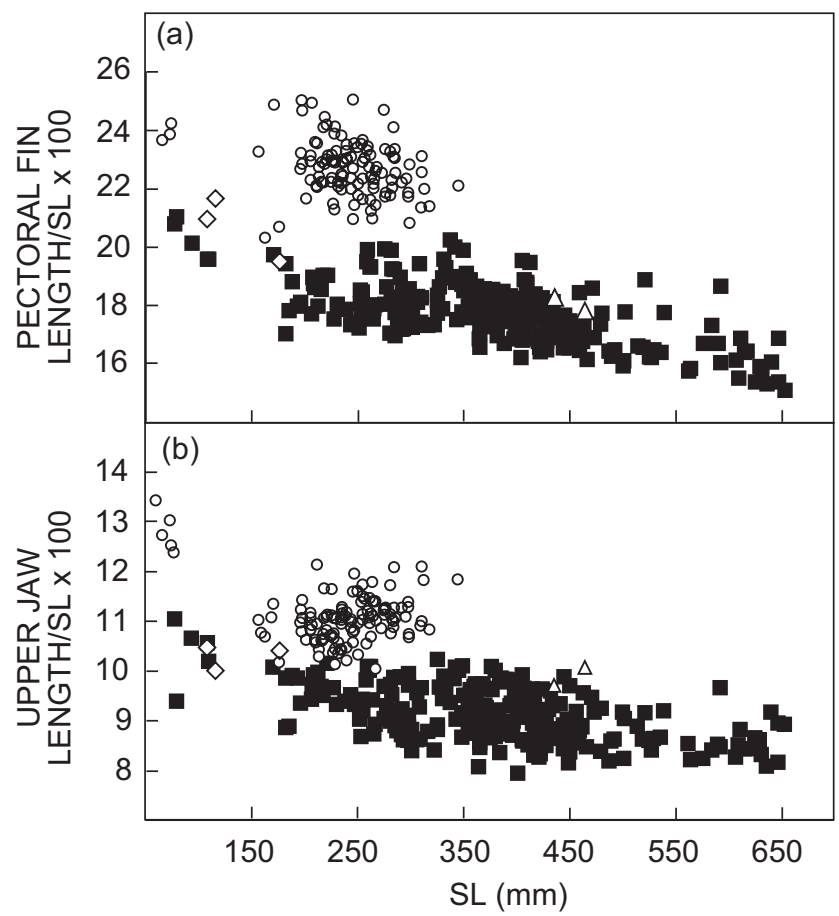

Figure 6: Relationship between (a) pectoral fin length and (b) upper jaw length as $\% \mathrm{SL}$ and SL for $U$. canariensis (circles), $U$. robinsoni (squares), U. steindachneri (diamonds) and $U$. ronchus (triangles) 

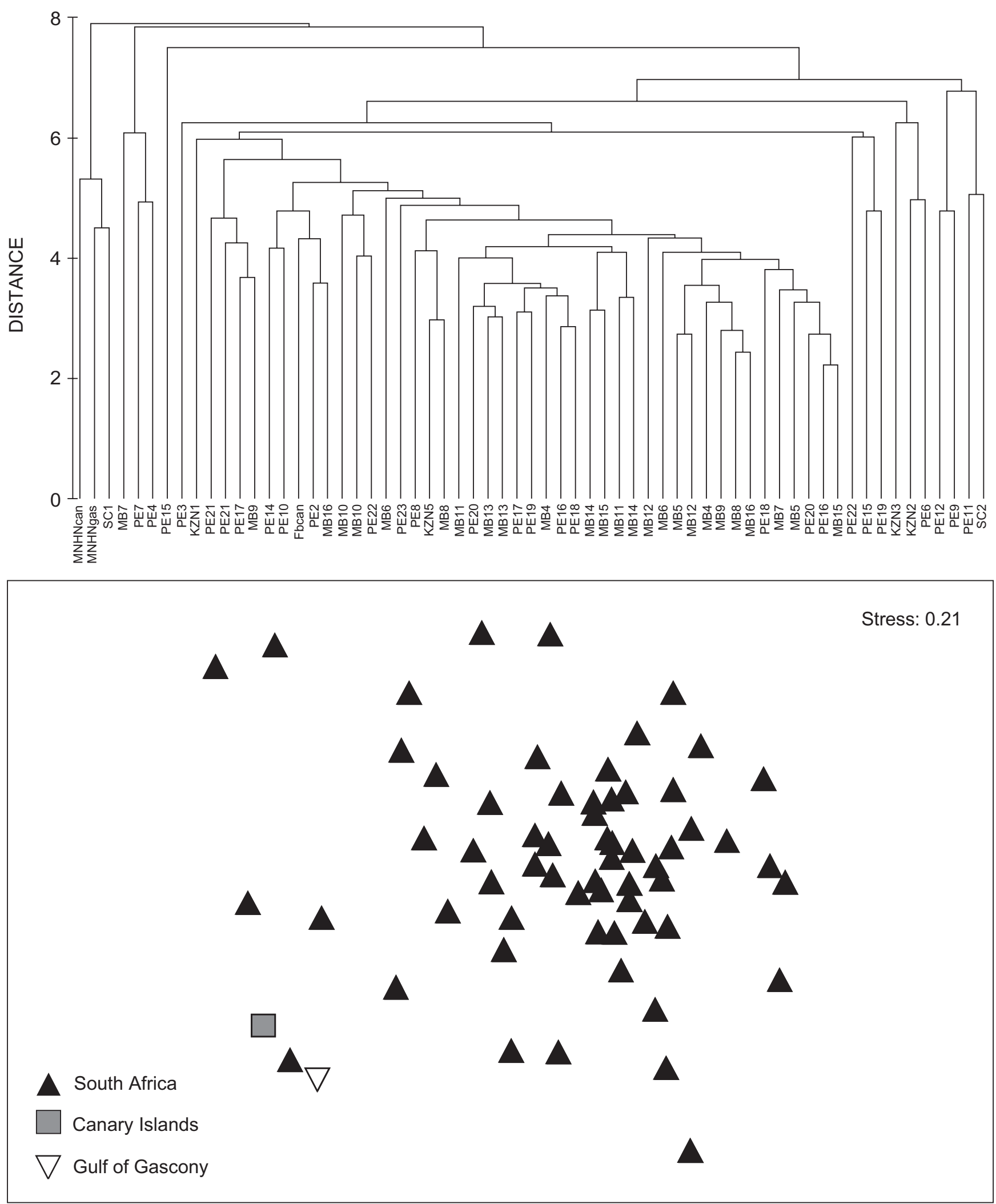

Figure 7: Dendrogram and MDS ordination plot showing relationship between 61 South African $U$. canariensis (collected between False Bay and Durban; 157-250mm SL) and specimens from the Canary Islands (MNHN 2983) and Mediterranean (MNHN 1898-0568). Dissimilarity matrix derived from the normalised Euclidean distance between specimens based on 19 measurements. MNHNcan $=\mathrm{Canary}$ Islands; MNHNgas = Gulf of Gascony; SC = Southern Cape; MB = Mossel Bay; PE = Port Elizabeth; KZN = KwaZulu-Natal; Fbcan = False Bay 


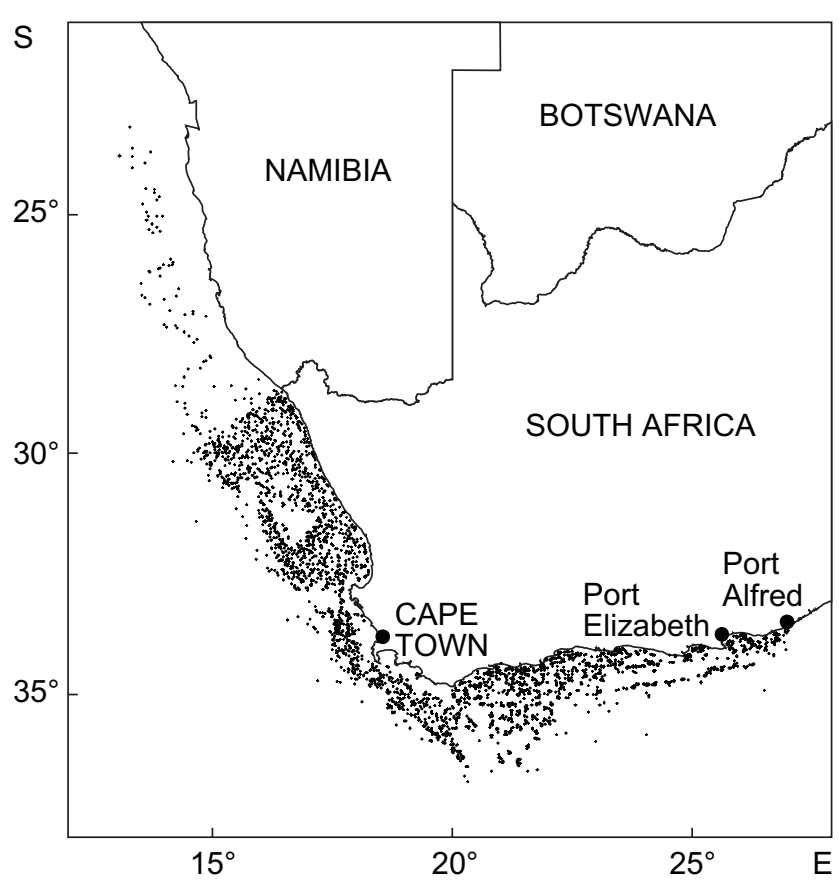

Figure 8: Distribution of demeral biomass survey trawls conducted by the FRS Africana between September 1986 and April 1999
Material examined

Gabon: MNHN 1913-0093 (F 177mm). Senegal: MNHN 19821298 (I 108mm); MNHN 1982-1299 (M 116mm).

Type: lost

\section{Diagnosis}

A medium-size Umbrina species (max. $47 \mathrm{~cm}$ TL, Chao and Trewavas 1990) with the following combination of characters: dorsal fin rays 28-31; gill-rakers 4-5 + 9; body depth 36-37\% SL; pre-dorsal length 36-38\% SL; pectoral fin length $20-22 \% \mathrm{SL}$; ventral caudal peduncle length 28-29\% SL; 3rd dorsal spine length 25-27\% SL; anal fin length 23-29\% SL; scale length 3.4-3.8\% SL; upper jaw length $10-11 \%$ SL; head length $31-32 \%$ SL; snout length $30 \% \mathrm{HL}$; horizontal orbit diameter $27-28 \% \mathrm{HL}$; nostril-orbit distance 4-5\% HL; preorbital bone depth 17-18\% HL.

\section{Description}

Counts and measurements for the three specimens examined are presented in Table 3. A deep-bodied Umbrina species with a relatively large orbit and short, rounded snout (orbit diameter subequal to snout length). The 1st dorsal and anal fins are very long; the pectoral short, shorter than the pelvic fin; caudal fin truncate or S-shaped and body scales large. Body colour of preserved specimens is uniform yellow-brown, with no dorsal-ventral trend; anal, pelvic and 1st dorsal fins are dark brown-black (Figure 12). Oblique white stripes with dark brown borders were very visible on all three specimens examined. Oblique stripes are very convoluted, particularly in the region of the pectoral fin and extend onto the head above and below the orbit.

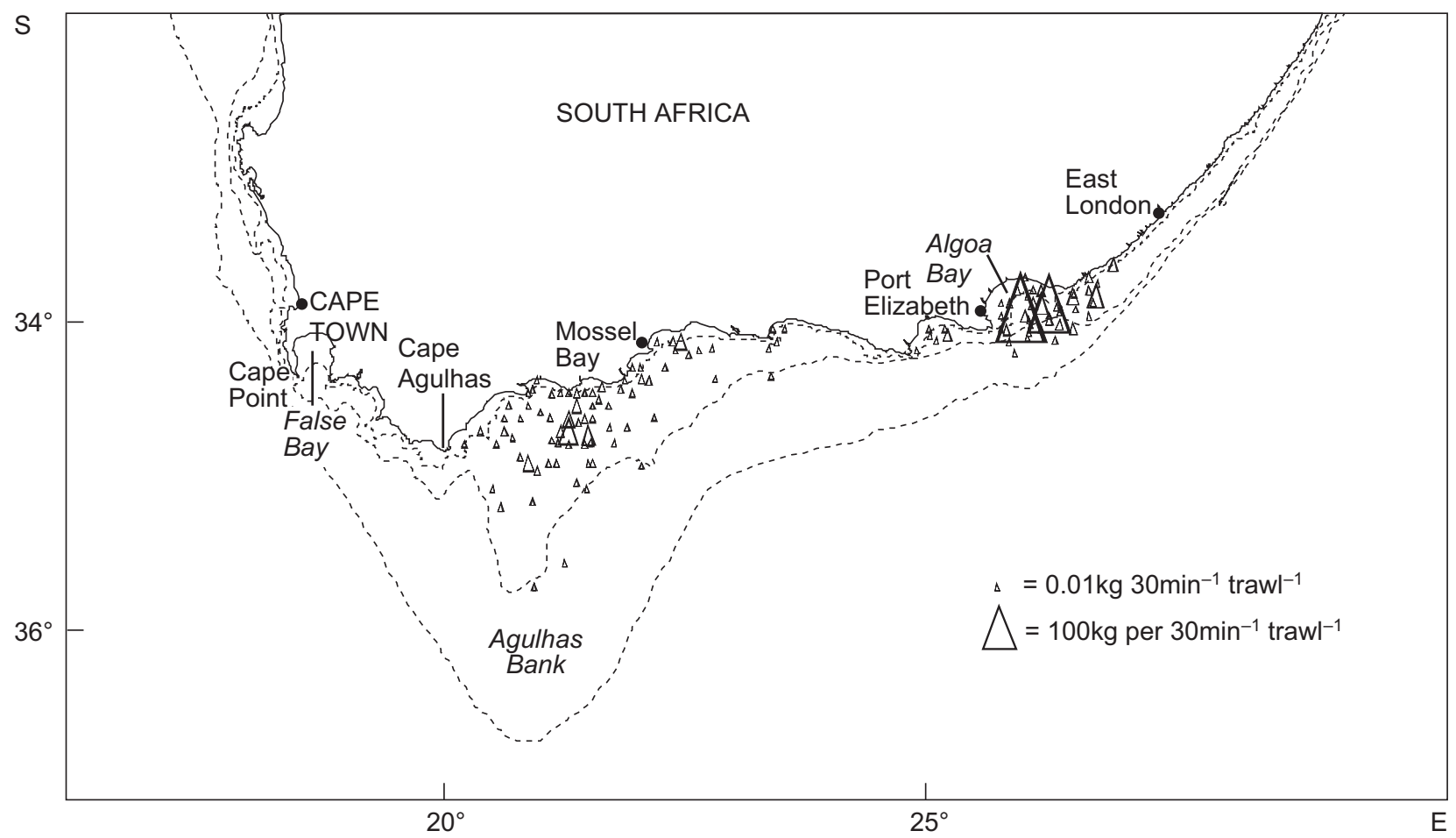

Figure 9: Distribution of cpue of U. canariensis in 238 demersal biomass survey trawls conducted between September 1986 and April 1999 


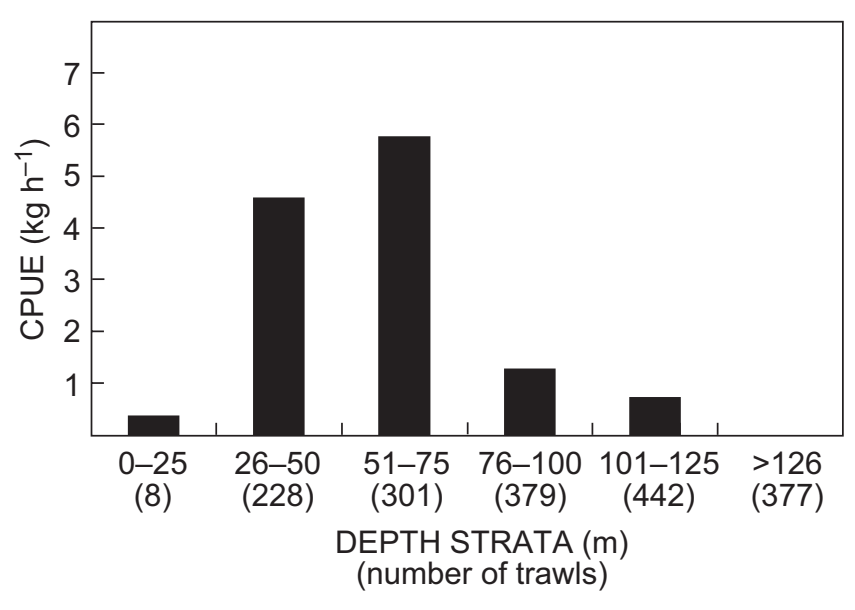

Figure 10: Cpue of $U$. canariensis caught in demersal biomass survey trawls by the FRS Africana for different depth strata. The number of trawls conducted in each depth strata are provided

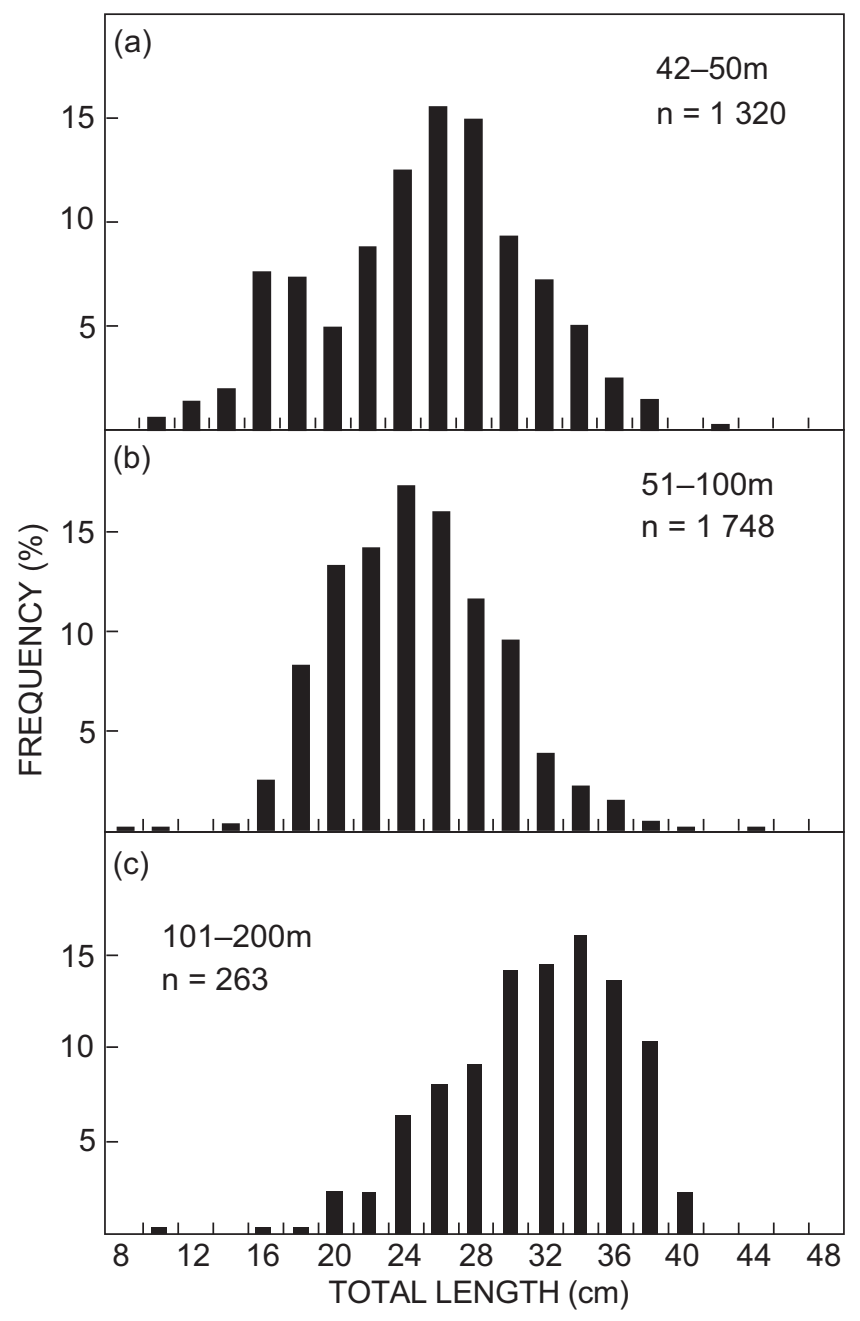

Figure 11: Size frequency distributions of $U$. canariensis caught in demersal biomass survey trawls by the FRS Africana for different depth strata

\section{Comparisons}

$U$. steindachneri differs from $U$. canariensis in having a shorter pectoral fin (Figure 6); longer 3rd dorsal spine (Figure 13); anal fin (Figure 4b); ventral caudal peduncle (Figure 5b); and a deeper preorbital bone depth (Figure 14). External colouration also differs, the oblique striping pattern being much more visible over the whole body, on the head and more convoluted in $U$. steindachneri (Figure 12). The dark pigmentation on the inner side of the operculum and triangular-shaped mark on the outer side of the operculum found on $U$. canariensis is absent on $U$. steindachneri.

\section{Remarks}

$U$. steindachneri was named by Cadenat (1951) and based on Umbrina cirrhosa var. canariensis of Steindachner (1882). No detailed description of this species' morphometrics appears to have been published and previous authors have only mentioned one or two distinguishing characteristics. For example, the depth of the preorbital bone and anal fin (Trewavas 1964) or the number of soft dorsal rays (Chao and Trewavas 1990). Consequently, there has been some doubt about the species validity, e.g. Chao (1986) suggesting synonymy with $U$. canariensis. This paper provides a description and identify distinguishing characters that separate $U$. steindachneri from the other sub-Saharan Umbrina species. Multivariate analyses also separated the three $U$. steindachneri specimens from similar-sized $U$. canariensis and $U$. robinsoni (Figure 15). However, this description is limited because only three small specimens $(10-17 \mathrm{~cm} \mathrm{SL})$ were examined and should be expanded using larger specimens. The drawing in Seret and Opic (1981) of a larger specimen (approximately $30 \mathrm{~cm} \mathrm{SL}$ ), however, suggests that the key characteristics (mainly relative fin size) are not unduly affected by allometry.

\section{Distribution}

West African coast from Guinée to Angola; 15-100m depths, rare (Chao and Trewavas 1990).

\section{Umbrina ronchus Valenciennes 1843}

(Figure 16)

\section{U. ronchus - Valenciennes 1843: 24 (Canary Islands).}

U. ronchus - Giglioli 1882: 535; Metzelaar 1919: 237; Chaine 1938: 65, PI. 6 (sagitta); Cadenat 1951: 221, Fig. 158; Trewavas 1964: 113; Palmer 1966: 423, PI. 6, (excluding False Bay specimen, PI. 7a); Trewavas 1973: 400; Druzhinin 1974: 25; Trewavas 1977: 281, Table 1; Chao and Trewavas 1981 (FAO sheets); Chao 1986: 873-874; Chao and Trewavas 1990: 825-826; Sasaki 1996: 84 (excluding Indian Ocean specimens).

Umbrina fusca - Dardignac 1958: 441, Fig. 46 (Morocco, type lost).

Sciaena ronchus - Collignon 1959: 8.

U. fusca - Dardignac 1961: 264, 266-267, Figs 4, 5c, 6-13; Williams 1968: 433; Blache et al. 1970: 301, Fig. 791.

\section{Holotype}

MNHN, A 5764 (432mm SL from Canary Islands, found in 1987, Bauchot and Desoutter 1987). 


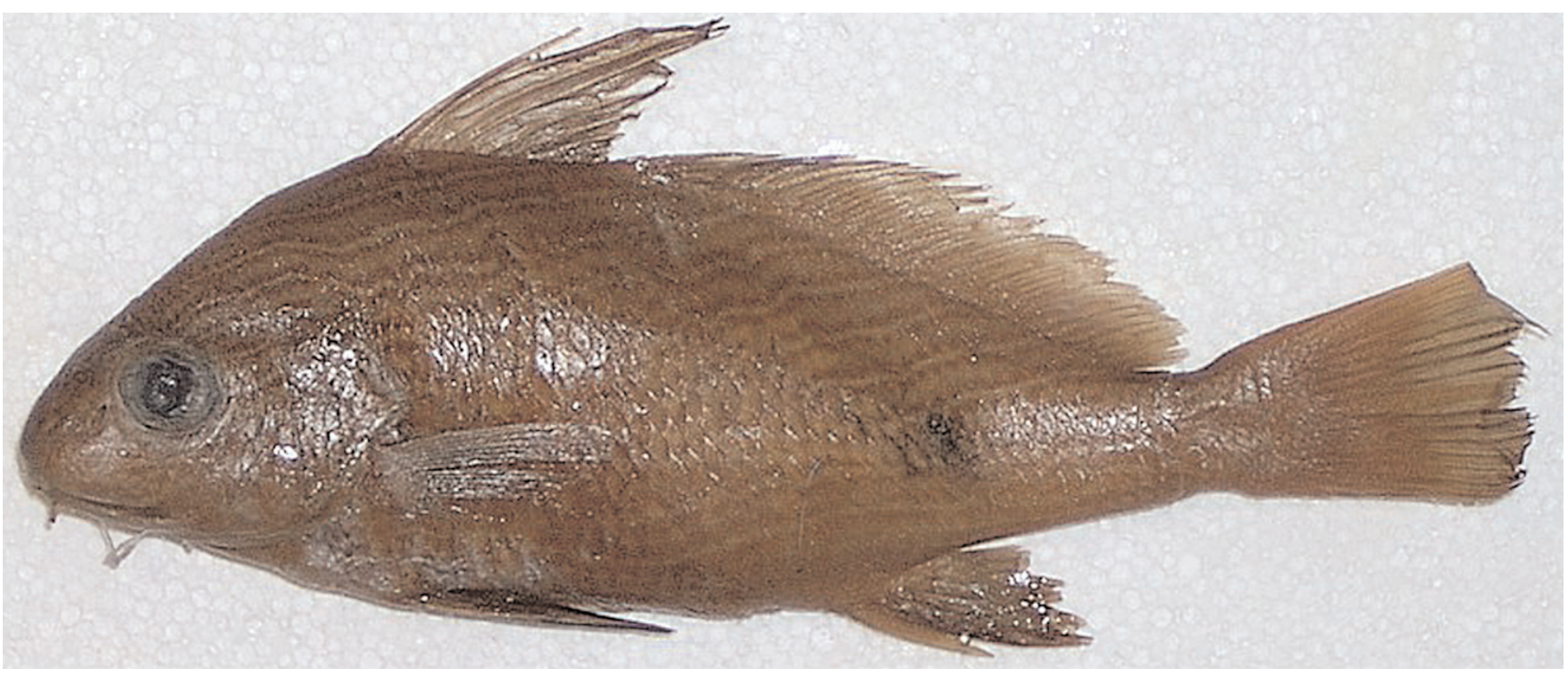

Figure 12: Female Umbrina steindachneri, 177mm SL, MNHN 1913-0093, Gabon

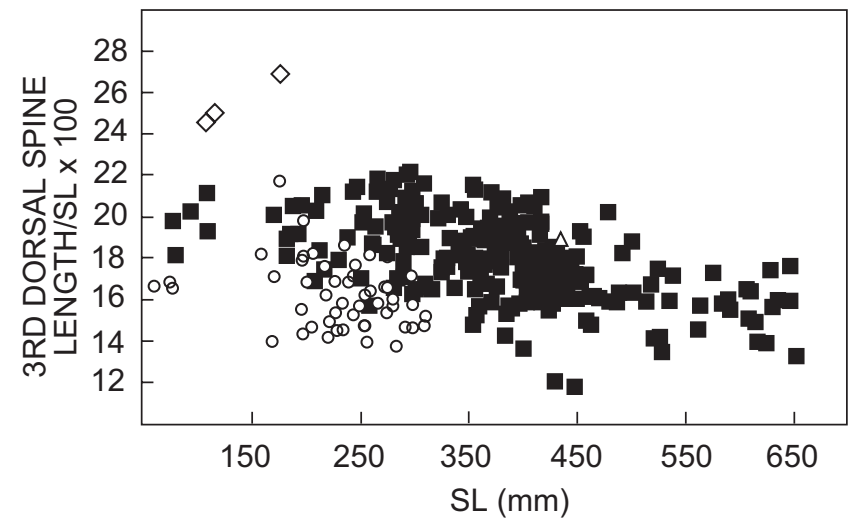

Figure 13: Relationship between 3rd dorsal spine length as \% SL and $\mathrm{SL}$ for $U$. canariensis (circles), $U$. robinsoni (squares), $U$. steindachneri (diamonds) and $U$. ronchus (triangles)

\section{Neotype}

BMNH 1964.12.30.1 (436mm SL from Canary Islands, designated by Palmer 1966).

\section{Material examined}

Canary Islands: BMNH 1964.12.30.1 (F 436mm); BMNH 1964.12.30.2 (M 465mm).

\section{Diagnosis}

Note: because there was access to only two alcohol-preserved specimens from the Canary Islands, the diagnosis and description below are supplemented by Dardignac's (1961) analysis of specimens from the coast of Morocco. The values given here are those recorded from the two Canary Islands specimens with Dadignac's (1961) ranges in parentheses.

A medium to large Umbrina species (attains $77 \mathrm{~cm} \mathrm{TL}$ ) with the following combination of characters: dorsal fin rays 25 (23-27); gill-rakers $3+8-9 ;^{2}$ body depth 31\% SL; predorsal length $38-39 \%$ SL; pectoral fin length $18 \% \mathrm{SL}$;

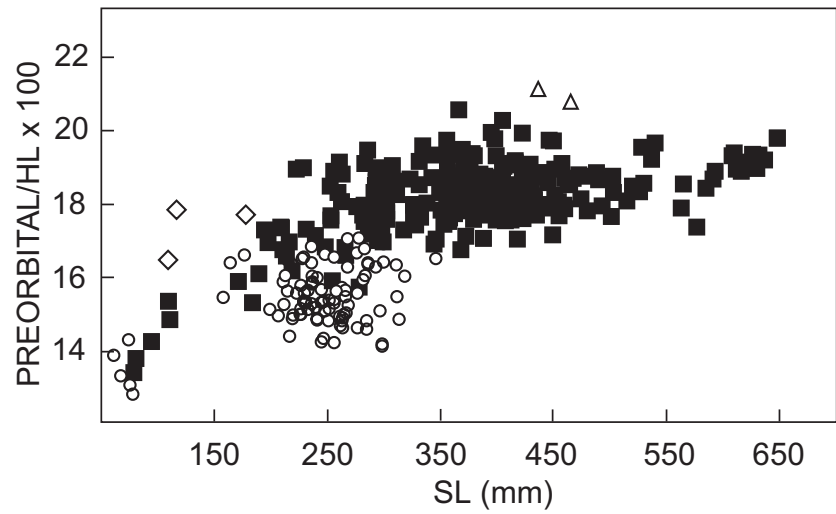

Figure 14: Relationship between preorbital bone depth as \% $\mathrm{HL}$ and $\mathrm{SL}$ for $U$. canariensis (circles), $U$. robinsoni (squares), $U$. steindachneri (diamonds) and $U$. ronchus (triangles)

ventral caudal peduncle length 27-28\% SL; 3rd dorsal spine length $19 \%$ SL; anal fin length 19\% SL; scale length 2.3-2.4\% SL; upper jaw length $10 \%$ SL; head length $31 \%$ SL; snout length $36.4(34-40) \% \mathrm{HL}$; horizontal orbit diameter 16 (14-25)\% HL; nostril-orbit distance 8-9\% HL; preorbital bone depth $21(18-24) \%$ HL.

\section{Description}

Counts and measurements for the two specimens examined are presented in Table 3. An elongate, moderately deepbodied Umbrina species with a relatively large, head and steeply inclined pre-dorsal surface. A clear inflection point on the dorsal head profile, near the end of the supraoccipital crest, is visible (Figure 16). Orbit small, less than half snout

\footnotetext{
2 Palmer (1966) records $5+7$ gill-rakers plus three tooth patches in the neotype, one tooth patch in the male; we counted $3+8-9$ when examining the same specimens. Dardignac (1961) does not supply gillraker counts
} 

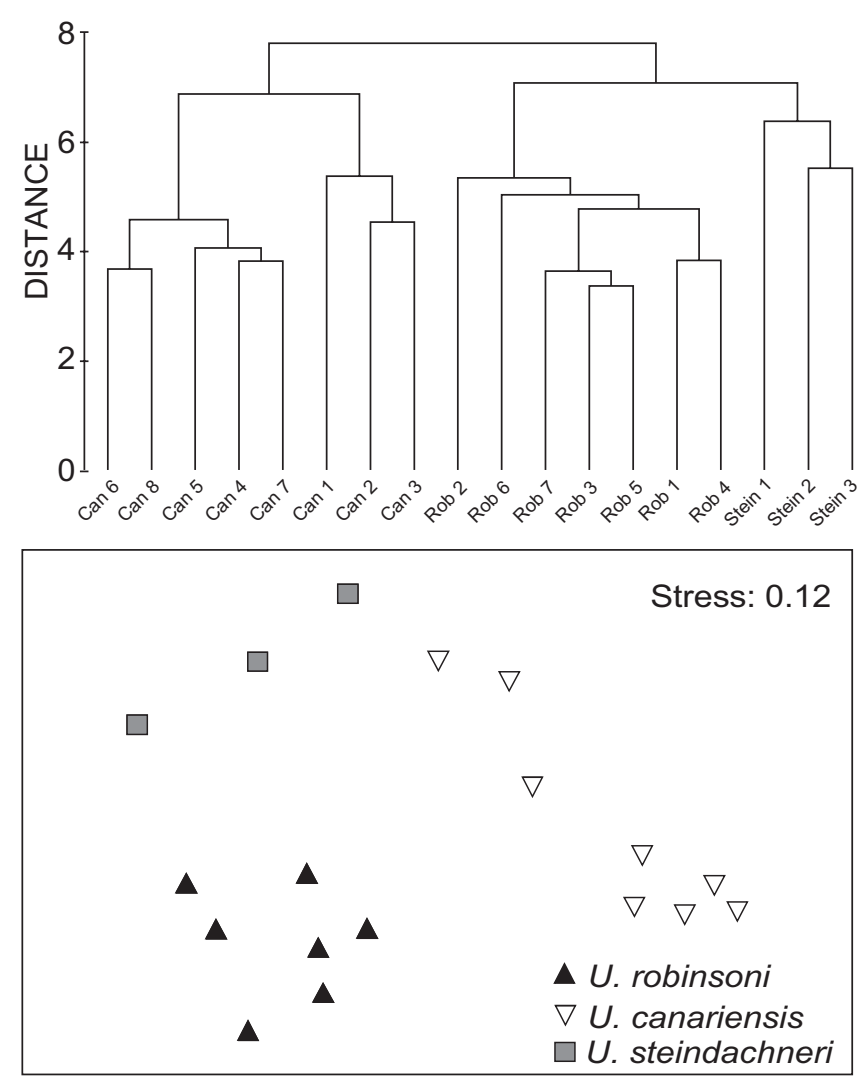

Figure 15: Dendrogram and MDS ordination plot showing relationship between seven South African U. robinsoni, 94-183mm $\mathrm{SL}$ (Rob 1-7), eight $U$. canariensis from the Canary Islands, Mediterranean, Morocco and South Africa, 60-176mm SL (Can $1-8)$ and three $U$. steindachneri from Senegal and Gabon, 108-177mm SL (Stein 1-3). Dissimilarity matrix derived from the normalised Euclidean distance between specimens based on 22 measurements and three counts

length; posterior nostril far from edge of the orbit (Table 3); snout thick, protrubent, preorbital bone deep; pectoral fin shorter than pelvic fin; caudal fin slightly emarginated, body scales short. Drumming muscles present in male specimen, absent in female.

Body colour of preserved specimens brown to yellow, dark dorsally and lighter ventrally; fins generally dark brown; a dusky, broad band apparent on head of one specimen, running laterally across the eye, but it is not known if this is a true feature or an artifact of preservation (Figure 16); no oblique brown stripes or markings evident on body. Dardignac (1961) reported that live specimens from Morocco are remarkably dull, mottled brown dorsally and white ventrally. Fish $<40 \mathrm{~cm}$ TL exhibit white blotches with irregular black borders ventrally and two longitudinal white stripes on second dorsal fin. This pigmentation is particularly visible in juveniles $(10-30 \mathrm{~cm}$ TL), but is not discernable in fish $>40 \mathrm{~cm}$ TL (Dardignac 1961).

The saggital otoliths of any $U$. ronchus were not examined here, but Schwarzhans (1993) reports on otoliths of three specimens from east of the Canary Islands. He describes them as very similar to those of $U$. canariensis, rather elongate and thick-set with a distinct post-central umbo on the outer face (particularly in the larger otoliths) and the rims of the smaller otoliths being clearly crenulated. His detailed illustrations show no evidence of a post-dorsal spine remnant.

\section{Comparisons}

See Table 3. $U$. ronchus differs from $U$. canariensis in having a less deep body (Figure 4a); shorter pectoral fins (Figure 6a); longer ventral caudal peduncle (Figure 5b); smaller scales (Figure 17); longer snout; smaller orbit; greater nostril-orbit distance (Figure 18); a deeper preorbital bone (Figure 14); and a lower modal number of dorsal fin rays and upper gill-rakers.

$U$. ronchus differs from $U$. steindachneri in having a less deep body (Figure 4a); shorter anal fin (Figure 4b) and 3rd dorsal spine (Figure 13); a deeper preorbital bone (Figure 14); smaller scales (Figure 17); smaller orbit; greater nostril-orbit distance (Figure 18); and a lower modal number of dorsal fin rays.

\section{Remarks}

Many authors (e.g. Palmer 1966, van der Elst 1981, Heemstra 1986, Chao and Trewavas 1990, Branch et al. 1994, Sasaki 1996) have referred to specimens from South African waters and the western Indian Ocean as $U$. ronchus. We believe that the species name $U$. robinsoni (Gilchrist and Thompson 1908) is valid (see description and comparisons below) and that $U$. ronchus is limited in distribution to the eastern Atlantic.

\section{Distribution and habitat}

West African coastal waters from Gibraltar to Angola and reported from the western Mediterranean. Found on rocky and sandy substrata from shore to $200 \mathrm{~m}$ depth, juveniles occurring in littoral areas, not known to enter estuaries (Chao and Trewavas 1990).

\section{Umbrina robinsoni Gilchrist and Thompson 1908}

(Figure 19)

U. robinsoni - Gilchrist and Thompson 1908: 182-183 (KwaZulu-Natal).

? Umbrina capensis - Pappe 1853:16. (Original description inadequate, type lost, Palmer 1966); Barnard 1927: 578, PI. 23, Fig. 4.

Umbrina angustilineata - Gilchrist and Thompson 1911: 38-39.

Sciaena capensis - Smith 1949: 227, PI. 26, Fig. 556 (in part).

Sciaena robinsoni - Smith 1949: 227, PI. 26, Fig. 557 (in part).

U. robinsoni - Trewavas 1964: 114; Trewavas 1977: 281, Table 1.

U. ronchus - Palmer 1966: 425, PI. 7; van der Elst 1981: 266; Mohan 1984: 5; Heemstra 1986: 619; Chao and Trewavas 1990: 825; Branch et al. 1994: 250, PI. 118.5; Randall 1995: 232, Fig. 604 (not juvenile in Fig. 605, which is probably $U$. canariensis); Sasaki 1996: 84.

\section{Holotype}

U. robinsoni: SAM 9966 (256mm SL, KwaZulu-Natal)

U. angustilineata: SAM 10559 (207mm SL, KwaZulu-Natal) 
Material examined

South Africa: Western Cape: RUSI 67470 (M 351mm); RUSI 67471 (F 626mm); RUSI 67472 (J 109mm); RUSI 67473 (M 197mm); RUSI 67474 (M 307mm); RUSI 67475 (M 351mm); RUSI 67476 (M 440mm); RUSI 67477 (M 515mm); RUSI 67478 (M 648mm); SAM 36050 (J 78mm); SAM 36051 (F 366mm); SAM 36052 (M 610mm); SAM 36053 (F 194mm); SAM 36054 (3 M 309mm, $369 \mathrm{~mm}$, 410mm; J 183mm); SAM 36055 (M 451mm; 2 F 585mm, $618 \mathrm{~mm}$ ); SAM 36056 (2 M 210mm, $255 \mathrm{~mm}$; F $231 \mathrm{~mm}$ ); SAM 36057 (3 F 398mm, 450mm, 488mm; M 490mm). Southern Cape: RUSI 35538 (M 377mm); RUSI 35534 (M 406mm); RUSI 35532 (M 522mm); RUSI 35539 (M 593mm); RUSI 67479 (F 263mm); RUSI 67480 (F 342mm); RUSI 67481 (F 410mm); RUSI 67482 (M 259mm); RUSI 67483 (M 299mm); RUSI 67484 (M 399mm); RUSI 67485 (M 474mm); RUSI 67486 (M 530mm); SAM 36058 (F $369 \mathrm{~mm}$ ); SAM 36059 (2 F 299mm; 472mm; M 396mm); SAM 36060 (3 M 481mm, 418mm, 346mm; F 262mm); SAM 36061 ( $F$ 349mm; M 377mm); SAM 36062 (3 F 425mm, 399mm, 449mm; 3 M 460mm, 260mm, 283mm). Eastern Cape: RUSI 12997 (F $641 \mathrm{~mm}$ ). KwaZulu-Natal: RUSI 11618a (244mm); RUSI 9148 (J 186mm); RUSI 61878 (F 654mm); RUSI 17459a (F 349mm); RUSI 17459b (365mm); RUSI 9501 (F 267mm); RUSI 60196 (J 183mm); RUSI 67487 (F 239mm); RUSI 67488 (F 355mm); RUSI 67489 (F 399mm); RUSI 67490 (F 430mm); RUSI 67491 (F 520mm); RUSI
67492 (F 616mm); RUSI 67493 (F 648mm); RUSI 67494 (M 254mm); RUSI 67495 (M 357mm); RUSI 67496 (M 454mm); RUSI 67497 (M 540mm); RUSI 67498 (M 608mm); SAM 9966 (M 256mm, holotype); SAM 10559 (M 207mm, holotype of $U$. angustilineata); SAM 36063 (2 M 526, 612mm; F 537mm); SAM 36064 (M 565mm; 2 F 591mm, 637mm); SAM 36065 (6 F 358mm, $402 \mathrm{~mm}, 429 \mathrm{~mm}, 378 \mathrm{~mm}, 460 \mathrm{~mm}, 297 \mathrm{~mm} ; 6 \mathrm{M} \mathrm{297mm,} \mathrm{423mm,}$ $356 \mathrm{~mm}, 406 \mathrm{~mm}, 281 \mathrm{~mm}, 459 \mathrm{~mm}$ ); SAM 36066 (F 248mm); SAM 36067 (M 266mm).

Additional material examined - Western Cape: 2001.3.1 (F 381mm); 2001.4.1 (M 422mm); 2001.6.2 (F 208mm); 2001.9.1 (F 209mm); 2001.15.2 (M 395mm); 2001.15.4 (M 380mm); 2001.15.7 (M 218mm); 2001.15.8 (F 216mm); 2001.15.11 (J 189mm); 2001.45.10 (M 446mm); 2001.45.11 (M 376mm); 2001.45 .12 (M $371 \mathrm{~mm}$ ); 2001.45.13 (M 384mm); 2001.46.2 (M 467mm); 2001.47.1 (F 171mm); 2001.47.3 (F 222mm); 2001.48.1 (F 228mm); 2001.48.2 (F 252mm); 2001.48.3 (F 429mm); 2001.48.5 (F 402mm); 2001.48.6 (F 402mm); 2001.48.7 (M 357mm); 2001.48.8 (M 379mm); 2001.48.10 (F 424mm); 2001.48.12 (F 430mm); 2001.48.14 (F 429mm); 2001.48.15 (M 372mm); 2001.48.16 (M 463mm); 2001.48.18 (M 563mm); 2001.48.19 (M 593mm); 2001.48.21 (M 433mm); 2001.48.23 (F 358mm); 2001.49.5 (M 311mm); 2001.50.1 (M 213mm); 2001.52.1 (F 455mm); 1993.1.1 (J 80mm); 1993.3.1 (J 110mm); 1993.3.2 (J 94mm). Southern Cape: 2000.1.1 (F 355mm);

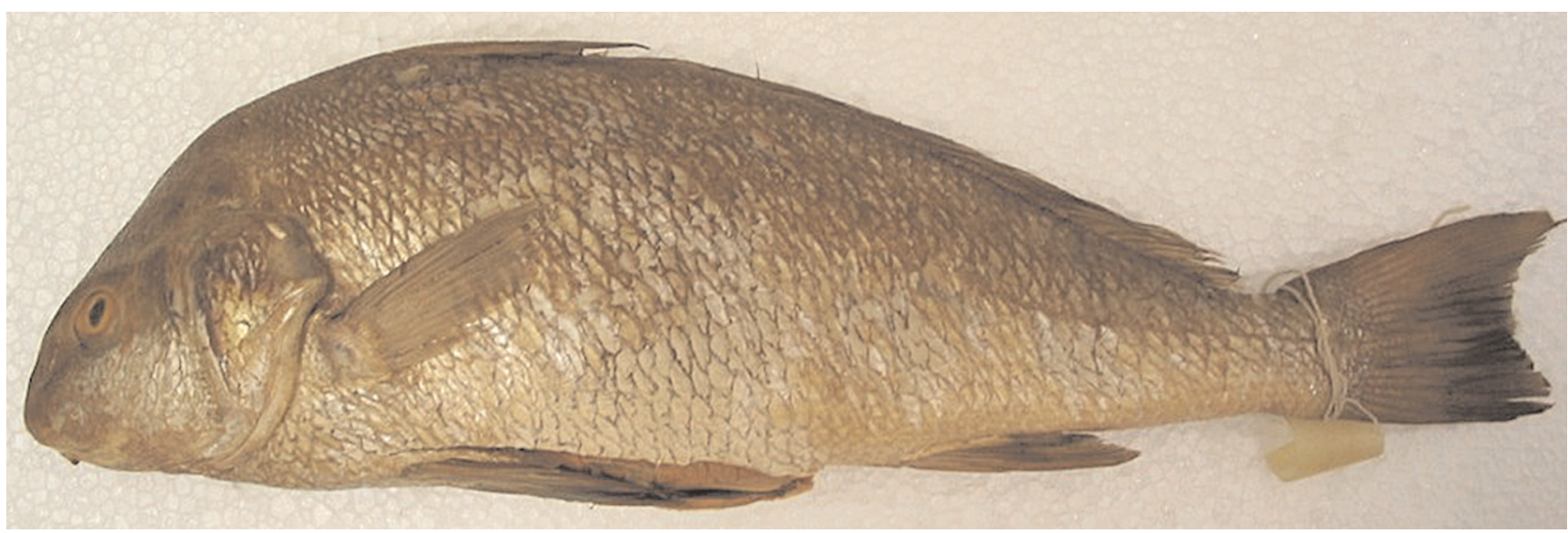

Figure 16: Female Umbrina ronchus, neotype, 436mm SL, BMNH 1964.12.30.1; Canary Islands

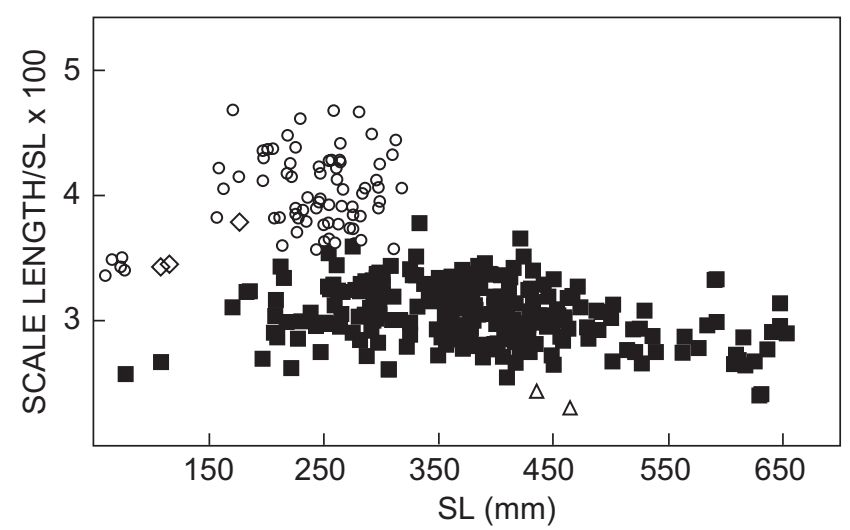

Figure 17: Relationship between scale length as \% SL and SL for $U$. canariensis (circles), U. robinsoni (squares), $U$. steindachneri (diamonds) and $U$. ronchus (triangles)

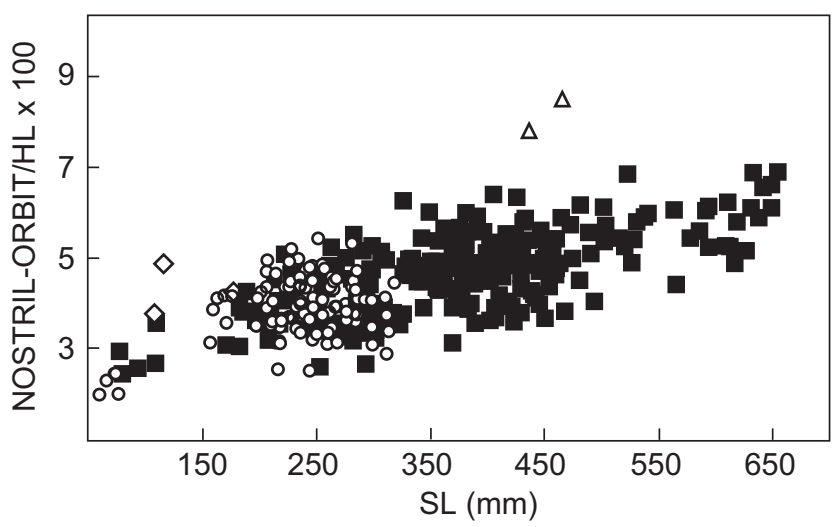

Figure 18: Relationship between nostril-orbit distance as \% $\mathrm{HL}$ and SL for $U$. canariensis (circles), $U$. robinsoni (squares), $U$. steindachneri (diamonds) and $U$. ronchus (triangles) 

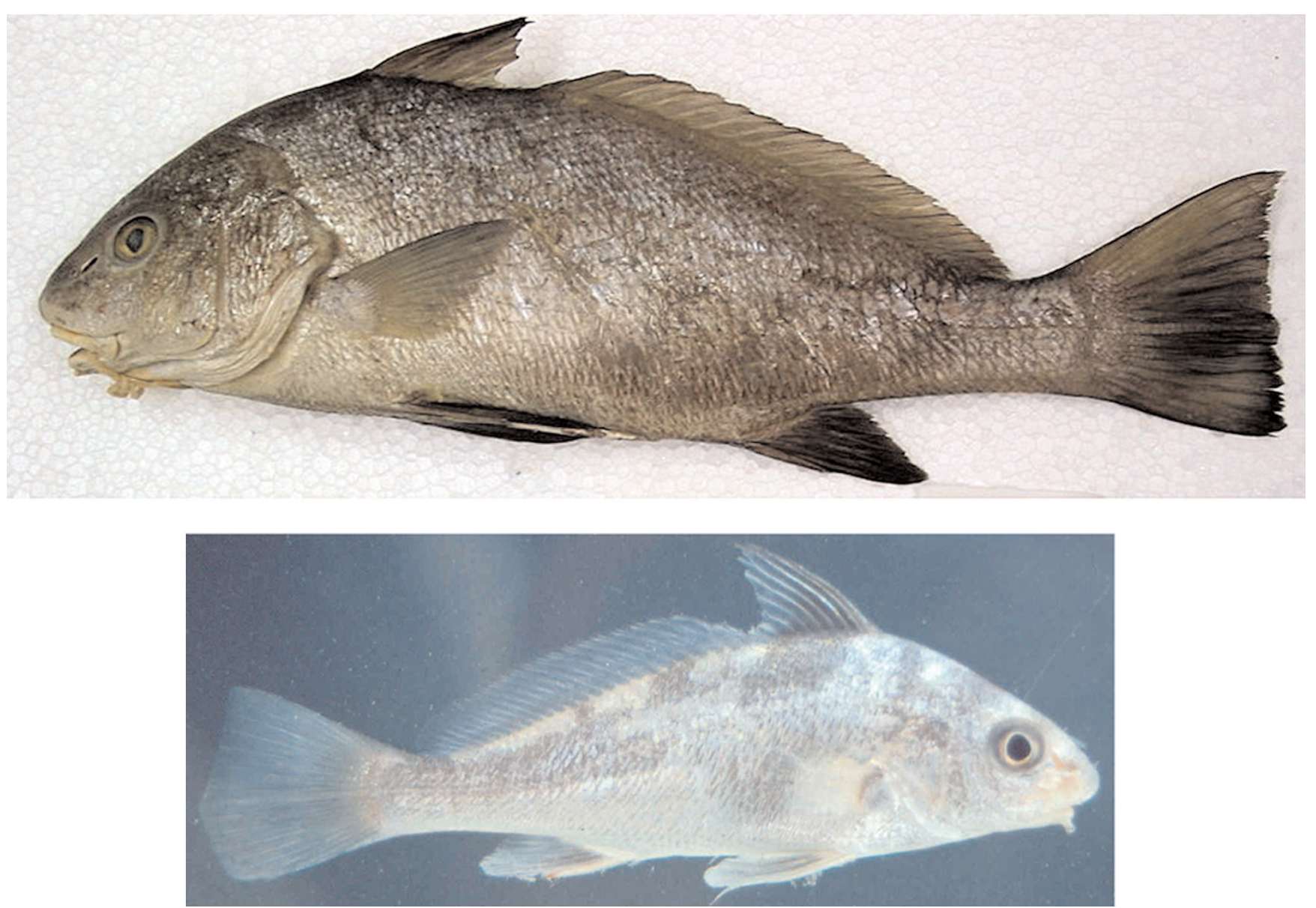

Figure 19: Female Umbrina robinsoni, 425mm SL, SAM 3602, Cape Agulhas, South Africa (top); juvenile approximately 100mm SL, False Bay (bottom)

2000.1.2 (M 410mm); 2000.1.3 (F 431mm); 2000.1.4 (F 405mm); 2000.1 .5 (F 353mm); 2000.1.6 (F 291mm); 2001.1.1 (F 405mm); 2001.1.2 (F 385mm); 2001.1.3 (F 388mm); 2001.1.4 (M 331mm); 2001.1.5 (F 334mm); 2001.23.3 (F 282mm); 2001.25.1 (M 501mm); 2001.26.1 (F 328mm); 2001.26.2 (M 368mm); 2001.26.4 (F 391mm); 2001.26.5 (F 451mm); 2001.26.7 (F 386mm); 2001.26.8 (F 343mm); 2001.26.10 (M 378mm); 2001.26.11 (F 401mm); 2001.26.12 (M 363mm); 2001.26.13 (M 361mm); 2001.27.1 (F 326mm); 2001.27.2 (M 413mm); 2001.27.5 (F 381mm); 2001.28.1 (M 380mm); 2001.28.2 (F 412mm); 2001.28.3 (M 331mm); 2001.28.4 (M 362mm); 2001.29.1 (M 416mm); 2001.29 .3 (F 435mm); 2001.29.4 (M 338mm); 2001.29.5 (M 405mm); 2001.29.7 (M 350mm); 2001.29.8 (F 357mm); 2001.29.11 (F 408mm); 2001.29.14 (F 464mm); 2001.29.15 (F 276mm); 2001.29.16 (F 446mm); 2001.29.17 (M 332mm); 2001.29.20 (M 353mm); 2001.29.21 (F 433mm); 2001.29.22 (M 442mm); 2001.29.23 (F 285mm). KwaZuluNatal: 2001.10.1 (F 493mm); 2001.11.1 (M 418mm); 2001.11.2 (F 397mm); 2001.11.3 (F 299mm); 2001.11.5 (F 282mm); 2001.11.6 (M 502mm); 2001.11.7 (M 528mm); 2001.11.11 (F 632mm); 2001.11.13 (M 577mm); 2001.11.15 (M 417mm); 2001.11.18 (F 298mm); 2001.11.19 (F 418mm); 2001.11.20 (F 382mm); 2001.11.22 (F 423mm); 2001.11.24 (F 630mm); 2001.11.25 (F 457mm); 2001.12.1 (M 297mm); 2001.12.2 (M 288mm); 2001.12.4 (M 383mm); 2001.12 .5 (M 369mm); 2001.12.6 (F 326mm); 2001.12.7 (M 278mm); 2001.12.8 (M 293mm); 2001.12.10 (M 317mm); 2001.12.11 (F 291mm); 2001.12.13 (M 366mm); 2001.12.14 (F $370 \mathrm{~mm}$ ); 2001.12.16 (M 389mm); 2001.12.17 (M 372mm);
2001.12.19 (M 385mm); 2001.12.20 (M 421mm); 2001.12.21 (F 293mm); 2001.12.22 (F 369mm); 2001.12.23 (F 362mm); 2001.12.27 (M 412mm); 2001.12.28 (F 407mm); 2001.12.29 (M $389 \mathrm{~mm}$ ); 2001.12.33 (F 410mm); 2001.12.35 (F 418mm); 2001.12.37 (M 387mm); 2001.12.39 (F 375mm); 2001.12.40 (F 438mm); 2001.12.42 (M 445mm); 2001.12.43 (M 443mm); 2001.12.47 (M 445mm); 2001.12.48 (F 416mm); 2001.12.49 (M 422mm); 2001.12.50 (M 480mm); 2001.13.1 (F 302mm); 2001.13.2 (F 296mm); 2001.13.3 (F 265mm); 2001.13.4 (M 281mm); 2001.13.5 (F 286mm); 2001.13.7 (F 326mm); 2001.13.8 (F 276mm); 2001.13.9 (M 286mm); 2001.13.12 (M 292mm); 2001.13.13 (F 302mm); 2001.13.14 (M 294mm); 2001.13.15 (F 344mm); 2001.13 .16 (F 299mm); 2001.13.17 (F 293mm); 2001.13.18 (M 302mm); 2001.13.19 (F 294mm); 2001.13.20 (M 323mm); 2001.14.1 (M 307mm); 2001.14.3 (F 287mm); 2001.14.4 (F 310mm); 2001.14.5 (F 253mm); 2001.14.6 (M 294mm); 2001.14.9 (F 253mm).

\section{Diagnosis}

A large Umbrina species (South African spearfishing record: $12.6 \mathrm{~kg}=985 \mathrm{~mm} \mathrm{TL}$ ) with the following combination of characters: dorsal fin rays 22-27 (25); gill-rakers 4-6 (5) + 6-10 (9); body depth 26-36 (31)\% SL; pre-dorsal length 31-40 (35)\% SL; pectoral fin length 15-21 (18)\% SL; ventral caudal peduncle length 26-34 (29)\% SL; 3rd dorsal spine length 12-22 (18)\% SL; anal fin length 16-24 (20)\% SL; scale length 2.4-3.8 (3)\% SL; upper jaw length 8-11 

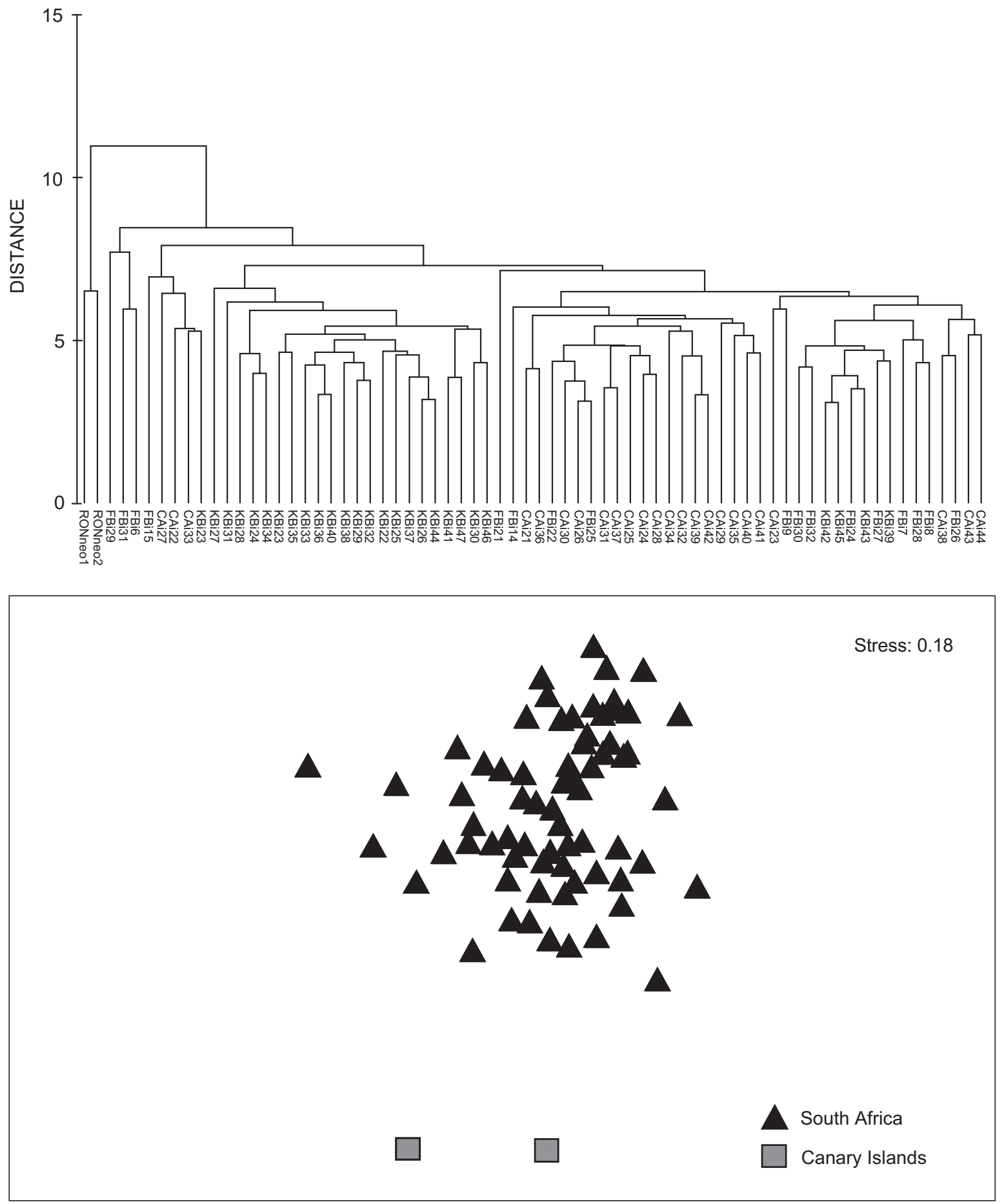

Figure 20: Dendrogram and MDS ordination plot showing relationship between 68 South African U. robinsoni (collected between False Bay and Kosi Bay; 401-493mm SL) and two specimens of $U$. ronchus (BMNH 1964.12.30.1-2) from the Canary Islands. Dissimilarity matrix derived from the normalised Euclidean distance between specimens based on 23 measurements and four meristic counts. RONneo1, 2 = Canary Islands; $\mathrm{FBi}=$ False $\mathrm{Bay} ; \mathrm{CAi}=$ Cape Agulhas; $\mathrm{KBi}=$ Kosi Bay

(9)\% SL; head length $26-32(29) \%$ SL; snout length $27-38$ (34)\% HL; horizontal orbit diameter $14-33(19) \% \mathrm{HL}$; nostril-orbit distance 2-5.4 (4)\% HL; preorbital bone depth $13-21(18) \% \mathrm{HL}$.

\section{Description}

Counts and measurements are presented in Table 3. Body relatively elongate and slender, becoming progressively more robust and deep with growth; upper jaw relatively short (end reaching to vertical of anterior half of orbit); snout 


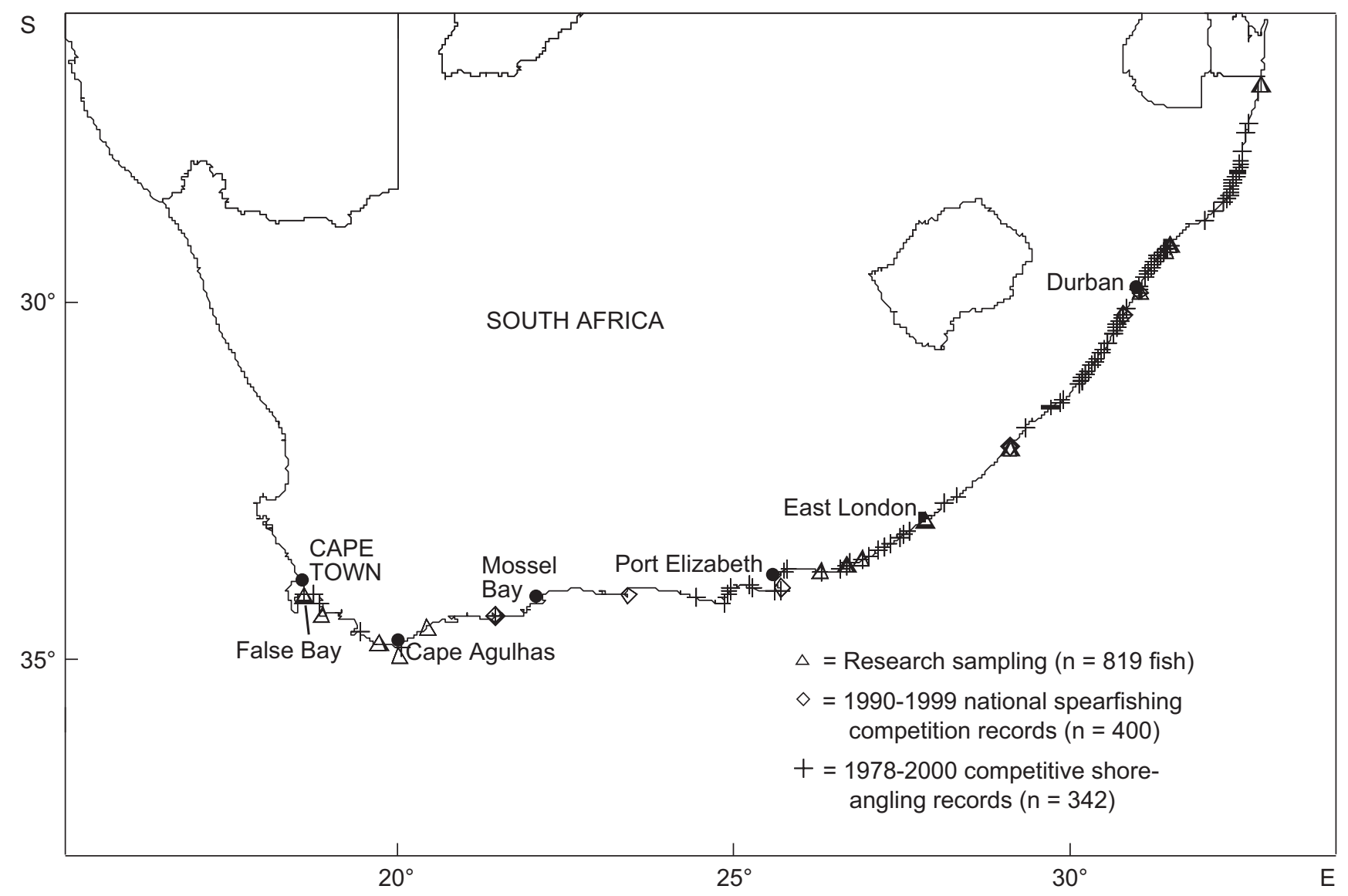

Figure 21: Distribution of $U$. robinsoni angling, spearfishing and research catches off the South African coast

moderately long (orbit 1.3-2.5 times in snout for fish $>15 \mathrm{~cm}$ ), blunt and protrudes beyond mouth, which is ventral. Posterior nostril close to margin of orbit; pectoral fin usually slightly shorter than pelvic fin; caudal fin truncate in smaller specimens $(<12 \mathrm{~cm})$, S-shaped or emarginate in larger fish. Drumming muscles present in males, absent in females.

The body colour ranges from slate-grey to dark brown dorsally and silver to white ventrally; fins dark brown to black (Figure 19). Oblique, narrow, wavy stripes, which appear electric blue underwater and white after death, are most visible on dorsal half of body of nearly all fish $<40 \mathrm{~cm}$; but are faint or absent on larger fish that become very dark overall. Juveniles $(<10 \mathrm{~mm})$ display a distinctive broad, dark cross on the flanks and may also exhibit wavy, white stripes (Figure 19). Inner side of operculum white or very lightly punctuate near the attachment of the gill-arches.

Otoliths oblong, rounded, and thin in smaller fish $(<400 \mathrm{~mm})$, becoming somewhat thicker in larger specimens (Figure 2). A post-central umbo is present on the lateral face, but this is not nearly as massive or pointed as in $U$. canariensis. Dorsal margin fairly straight and ventral margin rounded. A post-dorsal spine vestige was clearly visible on all $U$. robinsoni otoliths examined; i.e. the most posterior point of the otolith is at the dorsal corner. Otolith mea- surements are presented in Table 4 and otolith length and height to fish-length relationships are shown in Figure 3.

\section{Comparisons}

$U$. robinsoni differs from $U$. canariensis in having a less deep body (Figure 4a); shorter pre-dorsal; head; pectoral fins (Figure 6a); and upper jaw (Figure 6b); longer ventral caudal peduncle (Figure 5b); smaller scales (Figure 17); longer snout; smaller orbit (Figure 5a); a deeper preorbital bone (Figure 14); and a lower modal number of dorsal fin rays and upper gill-rakers (Table 3 ). The saggital otoliths of $U$. robinsoni are less elongate and much less thickset than in $U$. canariensis (Figures 2, 3). A post-dorsal spine vestige is present on $U$. robinsoni otoliths and absent on the otoliths of $U$. canariensis (see post-dorsal spine cauda measurement in Table 4). The body colour and nature of the striping pattern on the flanks differs markedly between the species: in $U$. robinsoni the oblique stripes are thin, wavy, white lines; in $U$. canariensis the oblique stripes are thicker, nearly straight and brown (Figures 1, 19). U. robinsoni lacks the triangle-shaped mark on the outer operculum and the dark pigmentation of the inner operculum that is found on $U$. canariensis.

$U$. robinsoni differs from $U$. steindachneri by having a less deep body (Figure 4a), shorter 3rd dorsal spine (Figure 13), shorter scales (Figure 17) and a lower modal number of dorsal fin rays (Table 3 ).

$U$. robinsoni differs from $U$. ronchus by having a shorter pre-dorsal length (Table 3); longer scales (Figure 17); shorter head (Table 3); bigger orbit (Table 3); shorter nostril- 
Table 5: Measurements of $U$. ronchus and $U$. robinsoni skull morphology made from radiographs

\begin{tabular}{|c|c|c|c|}
\hline Parameter & Area & $\mathrm{SL}(\mathrm{mm})$ & VT-SOC\% SL \\
\hline \multicolumn{4}{|c|}{ U. ronchus } \\
\hline BMNH 1964.12.30.1 & Canary Islands & 436 & 14.15 \\
\hline BMNH 1964.12.30.2 & Canary Islands & 465 & 13.93 \\
\hline \multicolumn{4}{|c|}{ U. robinsoni } \\
\hline$n=6$ & SWC & $429-490$ & $12.17-13.40(\bar{x}=12.78)$ \\
\hline$n=4$ & SC & $408-464$ & $12.5-13.7(\bar{x}=13.3)$ \\
\hline$n=2$ & KZN & 457,460 & $11.87,12.54(\bar{x}=12.2)$ \\
\hline$n=12$ & All regions & $408-490$ & $\bar{x}=12.86$ \\
\hline
\end{tabular}

SWC = False Bay - Cape Agulhas

$\mathrm{SC}=$ Cape Agulhas - Mossel Bay

$\mathrm{KZN}=$ East London - Moçambique border

VT-SOC $=$ Distance from ventral edge of 1 st vertebrae to dorsal terminus of supraoccipital crest

orbit distance (Figure 18) and a less deep preorbital bone (Figure 14). Multivariate analysis of similar-sized $U$. robinsoni and $U$. ronchus morphological data shows clear separation of the two species (Figure 20). The pre-dorsal profile of two species is also notably different; in $U$. robinsoni the curve from the snout to the dorsal fin is smoothly convex, whereas in $U$. ronchus it is steeply convex at first, but less so after the terminus of the supraoccipital crest (Figures 16, 19). Measurements taken from radiographs of the skulls of $12 U$. robinsoni and two similar-sized $U$. ronchus show that the distance between the attachment point of the first vertebra and the top of the supraoccipital crest is slightly greater in $U$. ronchus (Table 5). Part of the reason for the striking differences in the external appearance of the pre-dorsal surface may also be due to the steeper angle of the parasphenoid bone in $U$. ronchus. Although we did not have the opportunity to examine otoliths of $U$. ronchus, the drawings by Schwarzhans (1993) show differences from U. robinsoni otoliths in having a large post-central umbo on the outer surface and no evidence of a post-dorsal spine vestige. External pigmentation also appears to be different between the two species, with $U$. ronchus lacking the oblique, wavy striping pattern evident on the flanks of $U$. robinsoni and the unique cross-shaped pigmentation of juvenile $U$. robinsoni, which was not recorded on juvenile $U$. ronchus by Dardignac (1961).

\section{Remarks}

$U$. robinsoni and $U$. ronchus are clearly very similar and many authors have considered them to be synonymous, although no researchers compared a sufficiently large sample of South African specimens with similar-sized $U$. ronchus specimens from the type locality. However, we believe $U$. robinsoni to be valid; because the main differences between the two species; namely the nostrilorbit distance, preorbital bone depth, scale length and supraoccipital crest height, are 'hard tissue' features that are unlikely to be affected by differing preservation techniques. The measurements of these features fall outside the range for our large sample of $U$. robinsoni. The two species populations are also distinctly allopatric, with a distance of over $2000 \mathrm{~km}$ between Cape Point, the western limit of $U$. robinsoni range, and southern Angola, the likely southern extent of $U$. ronchus distribution. A significant environmental barrier separates the two species in the form of the Benguela upwelling system, which is very likely to prevent propagule dispersal between the two regions. A comparison of morphometric and genetic data between Angolan $U$. ronchus and South African $U$. robinsoni is, however, desirable to confirm or disprove this conclusion.

\section{Distribution and habitat}

Inshore coastal waters of the western Indian Ocean from Cape Point to at least Madagascar (recorded as $U$. ronchus by Mohan 1984) and possibly the Gulf of Oman (Mohan 1984, Heemstra 1986). Off the South African east coast, juveniles (<200mm TL) frequent mixed rock and sand surfzone habitats, whereas adult aggregations occur along sandy beaches, mixed rock and sand surf-zones and subtidal reefs; most commonly high structure limestone or sandstone reef. The distribution of catches of $U$. robinsoni by recreational shore-anglers and spearfishers in competitions is shown in Figure 21.

Acknowledgements - The following people and institutes are thanked for assistance in collection of specimens and providing material: $\mathrm{Mr} \mathrm{JJ}$ Dirkse-van Schalkwyk for donating fish from his beach-seine operation; anglers and spearfishers who assisted with sampling trips to De Hoop and Bhanga Nek; Paul Cowley, Brian Peterson and Bruce Mann who donated specimens from the Eastern Cape and KwaZulu-Natal; George Kant, Edwin Johannes, Cliffie Hart and Chris Wilke who collected specimens from commercial and research (during cruises aboard the FRS Africana and FRS Algoa) trawl catches; Gavin Aspeling for extracted data of Umbrina catches from the demersal biomass survey database; Pierre Pradervand for extracting data of competitive shoreangling catches from the National Marine Linefish System and Steph du Toit for providing data from national spearfishing competitions; Kerry Sink and James Stapely for providing an image of the Sodwana Bay $U$. canariensis; Oliver Crimmen and Patrick Campbell for lending specimens from the British museum of Natural History; Patrice Prouvost and Remi Ksas from the Muséum National d'Histoire Naturelle, Paris; Dr PA Hulley of the South African Museum for transporting specimens from Paris to Cape Town; the South African Institute of Aquatic Biodiversity, Grahamstown, and the South African Museum, Cape Town for access to specimens in their collections; Michael Bougaardt of the South African Museum who radiographed specimens and to Chris Wilke who photographed specimens. Thanks are due to Dr Phil Heemstra 
and Prof. Ning Labbish Chao for comments on an earlier draft of this manuscript. We especially thank Hayden Ferguson, Bridget Armstrong and Cloverly Lawrence of KwaZulu-Natal Wildlife for logistical support during the Bhanga Nek field trips. Thanks are also due to Peet Bothas for organising safe access to De Hoop, and to Cape Nature Conservation for accommodation. This work was funded by the National Research Foundation and by the Marine Living Resources Fund.

\section{References}

BADENHORST, A. and M. J. SMALE 1991 - The distribution and abundance of seven commercial trawlfish from the Cape south coast of South Africa, 1986-1990. S. Afr. J. mar. Sci. 11: 377-393.

BARNARD, K. H. 19251927 - A monograph of the marine fishes of South Africa. Ann. S. Afr. Mus. 21(1+2): 1065 pp.

BAUCHOT, M. L. and M. DESOUTTER 1987 - Catalogue critique des types de poissons du Muséum national d'Histoire naturelle. (Suite) (Famille des Sciaenidae). Bull. Mus. Natl. Hist. Nat. Ser. 4, Sect. Av. 9(no. 3 suppl.): 1-43.

BENNETT, B. A., ATTWOOD, C. G. and J. D. MANTEL $1994-$ Teleost catches by three shore angling clubs in the SouthWestern Cape, with an assessment of the effect of restrictions applied in 1985. S. Afr. J. mar. Sci. 14: 11-18.

BLACHE, J. 1962 - Liste des poissons signalés dans l'Atlantique Tropico Oriental Sud, du Cap des Palmes (4oLat.N) à Mossamédes (15oLat.S) (Province Guineo Equatoriale). Cah. ORSTOM, Sér. Océanogr. 1: 13-102 (Trav. Cent. océanogr. Pointe Noire).

BLACHE, J., CADENAT, J. and A. STAUCH 1970 - Cles de détermination des poissons de mer signales dans l'Atlantique oriental entre le $20 \mathrm{e}$ parallèle nord et le $15 \mathrm{e}$ parallèle sud. Faune trop. 18: 479 pp., Figures 1-1152.

BOULENGER, G. A. 1888 - An account of the fishes obtained by Surgeon-Major A. S. G. Jayakar at Muscat, East coast of Arabia. Proc. Zool. Soc., Lond. 1887: 653-667.

BRANCH, G. M., GRIFFITHS, C. L., BRANCH, M. L. and L. E. BECKLEY 1994 - Two Oceans. A Guide to the Marine Life of Southern Africa. Cape Town; David Philip: 360 pp.

CADENAT, J. 1950 - Poissons de mer du Sénégal. Inst. fr. Afr. noire, Initiations afr. 3: $345 \mathrm{pp}$.

CADENAT, J. 1951 - Lista provisoria dos peixes observados nas ilhas de Cabo Verd, de I de Maio a 24 de Juhno de 1950. Cabo Verde 2(19): 25-27.

CHAINE, J. 1938 - Recherches sur les otolithes des poissons. Etude descriptive et comparative de la sagitta des Teleosteens (suite). Act. Soc. Linn. Bordeaux 90: 2-258.

CHAO, L. N. 1986 - Sciaenidae. In Fishes of the North-Eastern Atlantic and the Mediterranean. Whitehead, P. J. P., Bauchot, M.-L., Hureau, J.-C., Nielsen, J. and E. Tortonese. (Eds). Paris; Unesco 2: 865-874.

CHAO, L. N. and E. TREWAVAS 1981 - Sciaenidae. In FAO Species Identification Sheets for Fishery Purposes. Eastern Central Atlantic (Fishing Areas 34 and 47 in part). Fischer, W., Bianchi, G. and W. B. Scott (Eds). Rome; FAO: 1-7: var. pagination.

CHAO, L. N. and E. TREWAVAS 1990 - Scianidae. In Check-list of the Fishes the Eastern Tropical Atlantic (CLOFETA). Quero, J. C., Hureau, J. C., Karrer, C., Post, A. and L. Saldanha (Eds). Paris; JNICT, Lisbon; SEI, Paris; and UNESCO 2: 813-826.

COLLIGNON, J. 1959 - La systématique des Sciénidés de l'Atlantique oriental. Bull. Inst. Pech. marit. Maroc. 7: 55-72.

CUVIER, G. 1817 — Le règne animal distribué d'après son organisation pour servir de base à l'histoire naturelle des animaux et d'introduction à l'anatomie comparée. 4. Paris: 255 pp. +15 Plates.
DARDIGNAC, J. 1958. In Furnestin, J., Maurin, C., Vincent, A., Coupe, R. and H. Boutiere. Revue Trav. Off. Pech. marit. 22: 381-487.

DARDIGNAC, J. 1961 - Les ombrines des cotes atlantiques du Maroc. Revue Trav. Inst. Pech. marit. 25(3): 262-279.

DAY, F. 1876 - The Fishes of India (2nd part). London: 169-368.

DRUZHININ, A. D. 1974 - Rasprostraneniye, biologiya i promysel gorbylevykh ryb. (Distribution, biology and commercial use of croakers). Moscow: $120 \mathrm{pp}$.

FENNESSY, S. T. 1994 - The impact of commercial prawn trawlers on linefish off the north coast of Natal, South Africa. S. Afr. J. mar. Sci. 14: 263-279.

FURNESTIN, J., DARDIGNAC, J., MAURIN, C., VINCENT, A., COUPE, R. and H. BOUTIERE 1958 - Donees nouvelles sur les poissons du Maroc atlantique. Revue Trav. Off. Pech. marit. 22: 381-487.

GIGLIOLI, E. H. 1882 - New deep-sea fish from the Mediterranean. Nature, Lond. 27: 198-199.

GILBERT, C. R. 1966 - Western Atlantic sciaenid fishes of the genus Umbrina. Bull. mar. Sci. 16(2): 230-258.

GILCHRIST, J. D. F. and W. W. THOMPSON 1908 - Descriptions of fishes from the coast of Natal. Ann. S. Afr. Mus. 6: 145-206.

GILCHRIST, J. D. F. and W. W. THOMPSON 1911 - Descriptions of fishes from the coast of Natal, Part 3. Ann. S. Afr. Mus. 11(2): 29-58.

GILCHRIST, J. D. F. and W. W. THOMPSON 1917 - A catalogue of sea fishes recorded from Natal, Part 2. Ann. Durban Mus. 1: 291-431.

GISTEL, J. 1848 - Naturgeschichte des Thierreichs. Fur hohere Schulen. Stuttgart; Scheitlin \& Krais: 216 pp.

GRIFFITHS, M. H., ATTWOOD, C. and R. THOMPSON $1999-$ New management protocol for the South African linefishery. Occ. Rep. S. Afr. Network coast. Oceanogr. Res. 5: 145-156.

HEEMSTRA, P. C. 1986 - Sciaenidae. In Smiths' Sea Fishes. Smith, M. M. and P. C. Heemstra (Eds). Berlin; Springer-Verlag: 616-619.

HUBBS, C. L. and K. F. LAGLER 1964 - Fishes of the Great Lakes Region. Ann Arbor; University of Michigan Press: 213 pp.

JAPP, D. W., SIMS, P. F. and M. J. SMALE 1994 - A review of the fish resources of the Agulhas Bank. S. Afr. J. Sci. 90(3): 123-134.

LAMBERTH, S. J., BENNETT, B. A. and B. M. CLARK $1994-$ Catch composition of the commercial beach seine fishery in False Bay, South Africa. S. Afr. J. mar. Sci. 14: 69-78.

LEVITON, A. E. R. H. G., HEAL, E. and C. E. DAWSON $1985-$ Standards in herpetology and ichthyology: Part 1. Standard symbolic codes for institutional resource collections in herpetology and ichthyology. Copeia 3: 802-832.

LINNAEUS, C. 1758 - Systema naturae, 10th Revised ed. 1. Stockholm; Laurentii Salvii: ii + 824 pp.

MANN, B. Q., SCOTT, G. M., MANN-LANG, J. B., BROUWER, S. L., LAMBERTH, S. J., SAUER, W. H. H. and C. ERASMUS 1997 - An evaluation of participation in and management of the South African spearfishery. S. Afr. J. mar. Sci. 18: 179-193.

METZELAAR, J. 1919 - Report on the fishes, collected by Dr. J. Boeke, in the Dutch West Indies, 1904-1905. With comparative notes on marine fishes of tropical West Africa. In Rapport Kolonie Curacao. Boeke, J. (Ed.). 's- Gravenhage. 2(1): 185-315.

MOHAN, R. S. L. 1984 - Sciaenidae. In FAO Species Identification Sheets for Fishery Purposes, Western Indian Ocean (Fishing Area 51). Fischer, W. and G. Bianchi (Eds). Rome; Food and Agriculture Organization of the United Nations. 4: p. 34.

MOREAU, E. 1874 - Poissons de France. Notes sur quelques espèces nouvelles des cotes de I' Océan. Revue Mag. Zool. 2: $115-119$. 
OSTROUMOFF, A. A. 1896 - Zwei neue Relicten-Gattungen in Azowschen Meere Zool. Anz. 19: 30.

PALMER, G. 1966 - Additional notes on some Umbrinine fishes (Family Sciaenidae). Ann. mag. Nat. Hist. 9(Ser. 13): 423-427.

PAPPE, C. W. L. 1853 - Synopsis of the Edible Fishes of the Cape of Good Hope. Cape Town: 34 pp.

RANDALL, J. E. 1995 - Coastal Fishes of Oman. Bathurst, Australia; Crawford House Publishing. 439 pp.

SANCHES, J. G. 1966 - Peixes de Angola (Teleosteos). Notes mimeogr. Cent. Biol. pisc. 46: iii + 227 pp. + 201 Figures.

SASAKI, K. 1989 - Phylogeny of the family Sciaenidae, with notes on its zoogeography (Teleostei, Perciformes). Mem. Fac. Fish. Hokkaido Univ. 36(1/2): 1-137.

SASAKI, K. 1996 - Sciaenid fishes of the Indian Ocean (Teleostei, Perciformes) Mem. Fac. Sci., Kochi University, Series D, Biology 16(17 March): 83-95.

SCHWARZHANS, W. 1993 - A Comparative Morphological Treatise of Recent and Fossil Otoliths of the Family Sciaenidae (Perciformes). Munchen; Verlag Dr. Friedrich Pfeil: 245 pp.

SERET, B. and P. OPIC 1981 - Poissons de mer de l'ouest africain tropical. Init. Documns. Tech. ORSTOM. Paris. 49: vi + $416 \mathrm{pp}$.

SMITH, J. L. B. 1949 - The Sea Fishes of Southern Africa. Cape
Town; Central News Agency: xviii +550 pp.

STEINDACHNER, F. 1882 - Beitrage zur Kenntnis der Fische Afrika's und Beschreibung einer neuen Paraphoxinus - Art aus Herzegowina. Denkschr. Akad. Wiss. Wien. 45(1): 1-18 + 6 Plates.

TREWAVAS, E. 1964 - The sciaenid fishes with a single mental barbel. Copeia 1: 107-117.

TREWAVAS, E. 1977 - The sciaenid fishes (croakers or drums) of the Indo West Pacific. Trans. zool. Soc. Lond. 33(4): 253-541.

VALENCIENNES, A. 1843 - Ichtyologie des lles Canaries, ou histoire naturelle des poissons rapportes par Webb \& Berthelot. In Histoire Naturelle des îles Canaries. Webb, P. B. and S. Berthelot (Eds). Paris. 2: 1-109.

VAN DER ELST, R. P. 1981 - A Guide to the Common Sea Fishes of Southern Africa. Cape Town; Struik: 367 pp.

WALKER, H. J. and K. W. RADFORD 1992 - Eastern Pacific species of the genus Umbrina (Pisces: Sciaenidae) with a description of a new species. Fishery Bull., Wash. 90: 574-587.

WILLIAMS, F. 1968 - Report on the Guinean trawling survey. Publ. Organ. Afr. Unity, Sci. Tech. Res. Commn 99(1): 828 pp.

ZAR, J. H. 1996 - Biostatistical Analysis, 3rd ed. Upper Saddle River, N. J.; Prentice-Hall: 622 pp. 